\title{
The Petäjäskoski Formation, a new lithostratigraphic unit in the Paleoproterozoic Peräpohja Belt, northern Finland
}

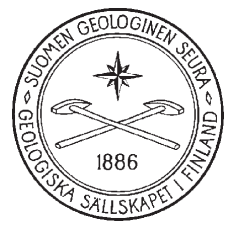

\author{
Markus KyläKoski ${ }^{1)} \dagger$, Eero Hanski ${ }^{1)^{*}}$ and Hannu Huhma ${ }^{2)}$ \\ 1) Department of Geosciences, P.O. Box 3000, 90014 University of Oulu, Finland \\ 2) Geological Survey of Finland, P.O. Box 96, 02151 Espoo, Finland
}

\begin{abstract}
This paper gives the first description of a newly-recognized, basin-wide metasedimentary unit in the Paleoproterozoic ( 2.4-1.9 Ga) Peräpohja Belt, northern Finland. The unit, which is named the Petäjäskoski Formation (PFm) after the single location where the rocks are known to be exposed, is situated stratigraphically in the middle part of the Kivalo Group between the quartzites of the $>2.22$ Ga Palokivalo Formation and the mafic volcanic rocks of the 2.1 Ga Jouttiaapa Formation.

The bulk of the PFm comprises phlogopitic-sericitic and albitic schists with abundant hematite as a diagnostic feature. Quartzite and dolomite interbeds are common. Based on drillcore and geophysical data, the succession is several hundreds of meters thick. The unit has prograde, chiefly lower greenschist facies mineral assemblages and, though being commonly intensely deformed, shows well-preserved sedimentary structures that imply deposition in shallow-water to subaerial environments. Based on the original lithological features, the Petäjäskoski Formation can be defined as a claystone-siltstone-sandstone-dolostone association. On the geochemical and stratigraphic basis, the albite schists likely represent albitized equivalents of the micaceous claystones and siltstones. They are intercalated with stratabound collapse breccias, up to tens of meters in thickness, with clasts composed mainly of bordering albite schist.

A mafic sill intruding the Petäjäskoski Formation yielded a U-Pb zircon age of $2140 \pm 11 \mathrm{Ma}$. The older, c. $2220 \mathrm{Ma}$, differentiated sills are not known to reach the stratigraphic level of the Petäjäskoski Formation and hence, the depositional age of the PFm sediments can be bracketed between c. 2220 and 2140 Ma. Detrital zircon grains dated from a quartzitic sample from the PFm show an Archean (c. 2650-3470 Ma) provenance.

The moderate to high $\mathrm{MgO}$ ( 6-13 wt.\%), $\mathrm{K}_{2} \mathrm{O}\left(\sim 3-8\right.$ wt.\%) and $\mathrm{FeO}_{\text {tot }}$ (8-15 wt.\%) contents, low $\mathrm{CaO}$ and $\mathrm{Na}_{2} \mathrm{O}$ contents, and abundant phlogopite and hematite make the mica schists unique among the metasedimentary rocks of the Finnish Karelian supracrustal belts. These features together with the abundance of dravititic tourmaline, the presence of pseudomorphic nodules potentially after gypsum and anhydrite, deposition under shallow-water conditions, and albitization and brecciation of the sedimentary strata suggest an evaporitic depositional environment.
\end{abstract}

Keywords: metasedimentary rocks, stratigraphy, petrography, geochemistry, depositional environment, evaporites, Paleoproterozoic, Peräpohja Belt, Finland

† Deceased on August 24, 2010

* Corresponding author email: eero.hanski@oulu.fi

Editorial handling: Joonas Virtasalo 


\section{Introduction}

Many base and precious metal ores occur in sedimentary basins where thick sequences of evaporitic strata were deposited (e.g., Warren, 1999), including sediment-hosted stratiform copper (SSC), sedimentary-exhalative (SEDEX) and iron-oxide copper gold (IOCG) deposits (e.g., Barton \& Johnson, 1996; Kirkham, 2001; Hitzman et al., 2005; Xavier et al., 2008). Evaporites may participate in oreforming processes in many ways (e.g., Warren, 1999). Foremost, fluids of evaporitic origin typically are chloride-rich brines that can dissolve and transport metals even at low temperatures. Evaporites may trap and seal the metal-carrying fluids and focus their flow. Reduced sulfate evaporites form important precipitation sites for the metals. Also, sulfide saturation in ultramafic-mafic magmas and the subsequent formation of orthomagmatic sulfide deposits may require an input of external sulfur, for which evaporites form a feasible source (e.g., Naldrett, 1999).

The Karelian supracrustal belts in the Fennoscandian Shield (index map in Fig. 1) comprise volcano-sedimentary formations that were deposited on Archaean basement blocks between c. 2.5-1.9 Ga ago and record roughly similar depositional histories (Laajoki, 2005; Ojakangas et al., 2001). The existence of evaporites in the Finnish Karelian sedimentary basins in eastern and northern Finland has been long postulated and their involvement in ore-forming processes has been envisioned. Tuisku (1985) and Frietsch et al. (1997) suggested that scapolitisation and albitisation of sedimentary and volcanic strata and the development of $\mathrm{Fe}$ and $\mathrm{Cu}-$ $\mathrm{Au})$ deposits in Karelian belts in northern Finland and Sweden might have involved evaporite-derived brines. According to Eilu (1994) and Vanhanen (2001), diagenetic albitization of sedimentary strata in the Central Lapland Greenstone Belt and Kuusamo Belt, respectively, was propably related to dissolution of evaporites. However, so far no conclusive evidence for the existence of evaporitic strata in Finland has yet been provided. In general, massive deposits of evaporites in the global Paleoproterozoic or Archean record are rare (Pope
\& Grotzinger, 2003; Warren, 2010). A notable exception is the recently discovered c. $2.0 \mathrm{Ga}$, thick halite and anhydrite occurrence in the Onega region, Russian Karelia (Morozov et al., 2010). Recognition of ancient evaporates is important not only due to the economic aspects noted above, but also because they provide means for regional stratigraphic correlation and paleo-oceanographic, paleogeographic and paleoclimatic reconstructions (e.g., Frimmel \& Jiang, 2001; Schröder et al., 2008).

The Peräpohja Belt is located in northwestern Finland (see the index map in Fig. 1) and is one of the Karelian supracrustal belts. In his earlier studies of the ore potential of the Peräpohja Belt, Kyläkoski (2004, 2007) proposed that evaporitic strata could occur in the unexposed upper part of the Palokivalo Formation. For testing this hypothesis, all available drillcores intersecting these unexposed sedimentary strata, reaching hundreds of metres in thickness, were re-examined. The studied drillcores and the recently discovered outcrops in a $2.5-\mathrm{km}$-long spill water channel at Petäjäskoski, dug through the sedimentary strata by a hydropower company in the early 1950 's, showed that the rocks consist chiefly of micaceous and albitic schists with quartzite and dolomite interbeds and are clearly distinct from the quartzitic major part of the Palokivalo Formation. Significantly, microscopic investigations and chemical analyses revealed that these rocks are characterized by mineral and chemical compositions that render them unique among the metasedimentary rocks of the Finnish Karelian successions. Moreover, they exhibit features indicative of an evaporitic depositional environment. It is therefore warranted to separate this micaceous and albitic sequence from the upper part of the Palokivalo Formation into a lithostratigraphic unit of its own. According to the single location where the rocks are exposed, the channel at the Petäjäkoski hydropower station, the sequence is assigned to the Petäjäskoski Formation.

The aim of this article is to give the first description of the geology, petrography, mineralogy and geochemistry of the Petäjäskoski Formation (PFm) and complement the otherwise well-defined lithostratigraphy of the Peräpohja Belt (e.g., Pert- 


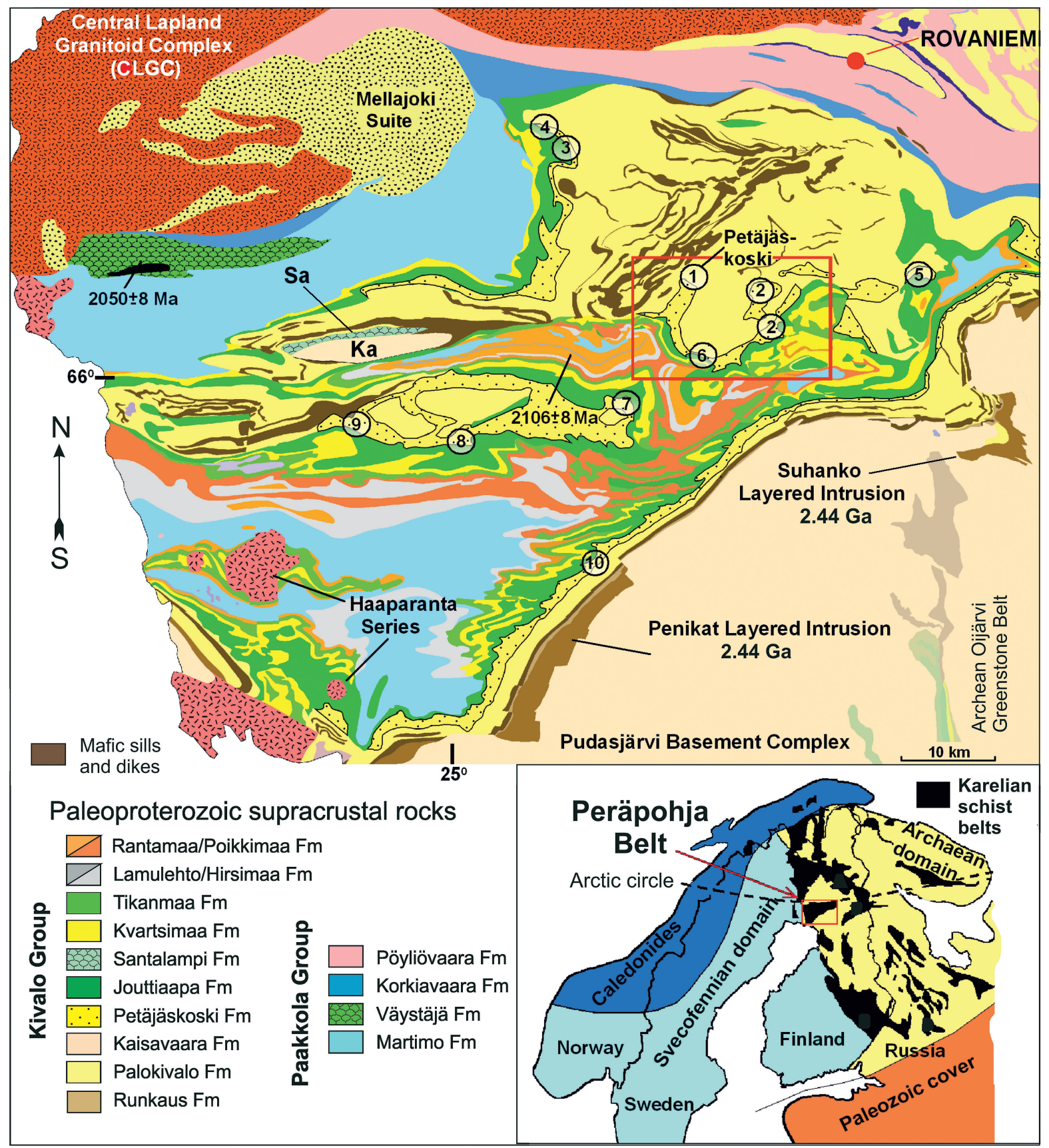

Fig. 1. Stratigraphic map of the Peräpohja Belt (modified after Bedrock of Finland - DigiKP, Digital map database, version 1.0, Geological Survey of Finland, 2011, http://www.geo.fi/en/bedrock.html). For the lithology of the lithostratigraphic formations, see Fig. 2. The numbers represent the locations of the studied drilling sites and the Petäjäskoski water channel: 1) Petäjäskoski, 2) Lapioaapa, 3) Kuusivaara, 4) Rumatmaat, 5) Haukitaipale, 6) Vammavaara, 7) Ossauskoski, 8) Viidanmaa, 9) Kaisajoki, 10) Jouttiaapa. The red box marks the location of the geophysical maps presented in Fig. 3. Sa: Santalampi Formation, Ka: Kaisavaara Formation. The index map showing the location of the Peräpohja Belt in the Fennoscandian Shield after Melezhik et al. (2000). 
tunen \& Vaasjoki, 2001; Perttunen \& Hanski, 2003). In order to constrain the depositional time of the Petäjäskoski Formation, we determined the age of a cutting mafic sill using the U-Pb zircon method. Also detrital zircon grains of a quartzitic sample from the Petäjäskoski Formation were dated. Finally, considering the atypical mineralogical and geochemical characteristics of the PFm, the origin of these features and the potential depositional environment of the formation are discussed.

\section{Regional geologic setting}

The Paleoproterozoic Peräpohja Belt forms a 170$\mathrm{km}$-long, $80-\mathrm{km}$-wide, triangular belt of wellpreserved volcanic and sedimentary rocks (Fig. 1) deposited in both continental and marine environments. It represents a failed intra-continental rift with c. $500 \mathrm{Ma}$ of geologic history recorded by a stratigraphic succession c. 5 kilometers in thickness. The Peräpohja Belt is bordered in the southeast by the Archean Pudasjärvi complex, which forms the basement of the belt, and in the north, it is bordered by granitoids of the Central Lapland Granitoid Complex $(\sim 1800 \mathrm{Ma})$. In the west, after crossing the Finnish-Swedish border, the Peräpohja Belt is truncated by the N-S-trending Baltic-Bothnian megashear (not shown), which separates it from the Kalix Belt (Berthelsen \& Marker, 1986; Laajoki, 2005).

Apart from the northern and north-eastern margins of the belt, which have experienced a higher grade of metamorphism and tectonism, the lithostratigraphy of the Peräpohja Belt is in general well-established (e.g., Perttunen, 1985; Hanski, 2001) though some refinements have been made recently (Perttunen \& Hanski, 2003). The supracrustal sequence is divided into two major lithostratigraphic units, the Kivalo and Paakkola Groups (Fig. 2). The c. 3- to 4-km-thick Kivalo Group commences with basal conglomerates of the Sompujärvi Formation, which lie on Archean

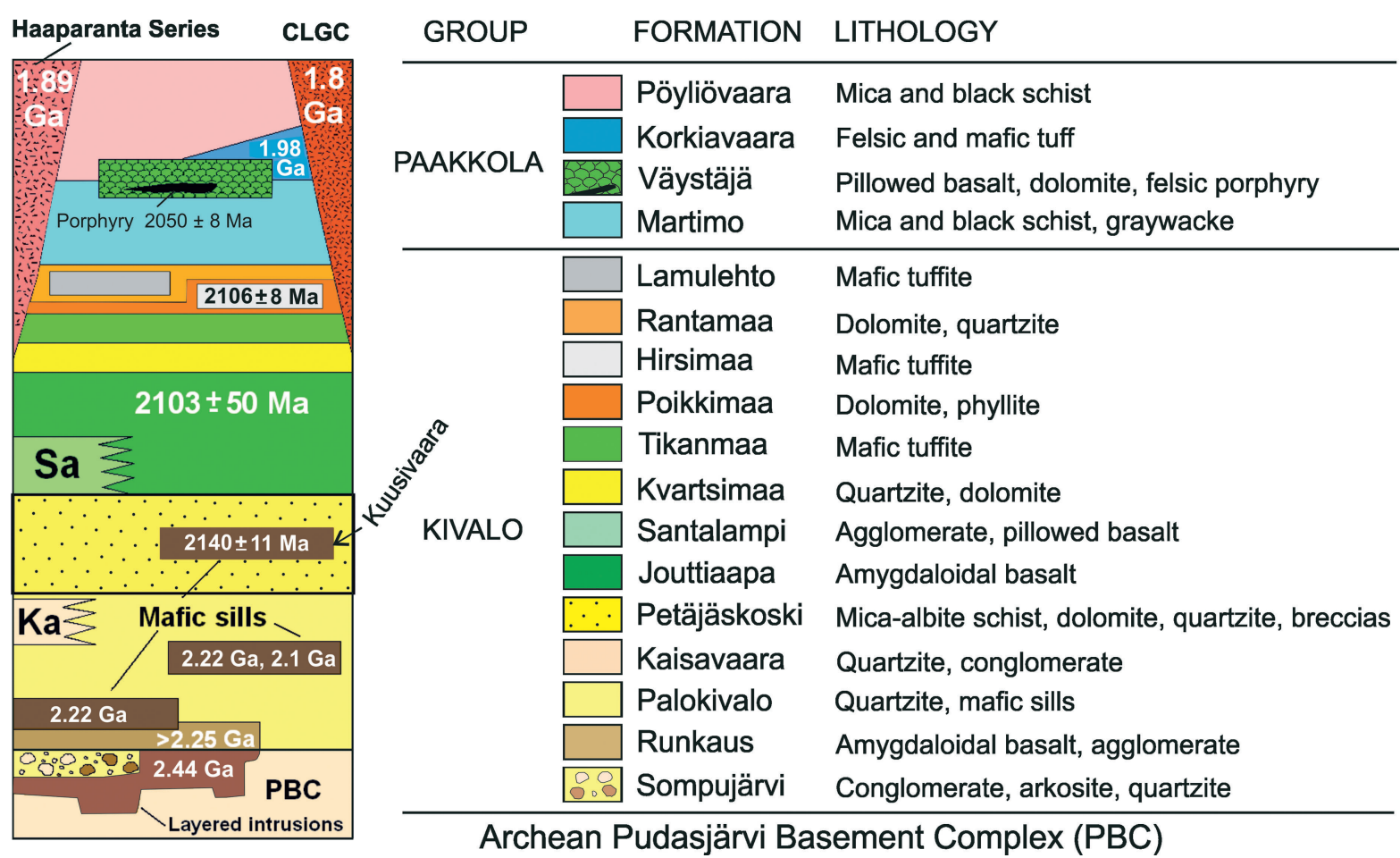

Fig. 2. Lithostratigraphy of the Peräpohja Belt after Perttunen \& Hanski (2003) complemented with the Petäjäskoski Formation. Sa = Santalampi Formation, Ka = Kaisavaara Formation, CLGC = Central Lapland Granitoid Complex. Age data from Perttunen and Vaasjoki (2001), Hölttä et al. (2003), Karhu et al. (2007), and Hanski et al. (2010). 
granitoids of the Pudasjärvi Basement Complex and locally on remnants of the -2440 Ma mafic-ultramafic layered intrusions forming a fragmentary belt along the SE border of the Peräpohja Belt (Fig. 1). The deposition of the conglomerates on the intrusions implies crustal uplifting and extensive erosion of unknown duration after the intrusive magmatism (e.g., Hanski \& Melezhik, 2012). The overlying subaerial basalts of the Runkaus Formation, which are c. 100-200 m thick and have a minimum age of c. $2250 \mathrm{Ma}$ (secondary titanite, $\mathrm{Pb}-\mathrm{Pb}$ data; Huhma et al., 1990), are in turn overlain by orthoquartzites and arenites of the c. 1-km-thick Palokivalo Formation. Wave- and current-ripple marks in quartzites and desiccation cracks in shale interbeds in the upper part of the formation attest deposition in shallow water and occasional subaerial exposure (Härme, 1949; Ojakangas, 1965; Perttunen \& Hanski, 2003). Lower parts are typically intruded by differentiated mafic sills of the c. 2220 Ma gabbro-wehrlite association (Hanski et al., 2010). Younger mafic sills and dikes with an age c. $2100 \mathrm{Ma}$ intrude quartzites, too (Perttunen \& Vaasjoki, 2001).

The Petäjäskoski Formation (PFm) overlies the Palokivalo Formation and is situated stratigraphically in the middle part of the Kivalo Group. It is overlain by a 300 - to 1000 -m-thick suite of subaerially erupted continental flood basalts belonging to the Jouttiaapa Formation, which has been dated at $2105 \pm 50 \mathrm{Ma}$ (whole-rock Sm-Nd data; Hölttä et al., 2003). The sericitic quartzites of the Kaisavaara Formation and the pyroclastic and pillowed basalts of the Santalampi Formation, apparently deposited after the Kaisavaara Formation, are marked with appreviations $\mathrm{Sa}$ and $\mathrm{Ka}$, respectively, in Figs. 1 and 2. Their stratigraphic position is still problematic; Perttunen and Hanski (2003) correlated them tentatively with the Palokivalo and Jouttiaapa Formations, respectively.

The upper part of the Kivalo Group is composed of orthoquartzites of the Kvartsimaa Formation $(50-200 \mathrm{~m})$ with local stromatolitic dolomite interbeds, mafic tuffites of the Tikanmaa (200-300 m), Hirsimaa $(200-300 \mathrm{~m})$ and Lamulehto Formations $(-100 \mathrm{~m})$, stromatolitic dolomites of the Rantamaa Formation (100-300 $\mathrm{m})$ and dolomites and phyllites of the Poikkimaa Formation (Fig. 2). The tuffites of the Hirsimaa Formation have been dated at $2106 \pm 8 \mathrm{Ma}(\mathrm{U}-\mathrm{Pb}$ zircon data; Karhu et al., 2007) and give a minimum age for the underlying units.

The Paakkola Group ( $>1-2 \mathrm{~km}$ ) begins with the Martimo Formation, which comprises extensive mica schists with graphite- and Fe sulfide-bearing black schist interlayers, and turbidites deposited in a rapidly deepening oceanic basin. Pillowed basalts of the Väystäjä Formation occur within the mica schists, and associated felsic porphyries have yielded a U-Pb zircon age of $2050 \pm 8 \mathrm{Ma}$ (Perttunen \& Vaasjoki, 2001). The Pöyliövaara Formation, which consists mainly of mica schists, represents the youngest sedimentary rocks in the Peräpohja Belt. They are underlain by felsic and mafic tuffs of the Korkiavaara Formation, which contain zircons dated at c. $1980 \mathrm{Ma}$ (Hanski et al., 2005). The Mellajoki Suite at the northern margin of the Peräpohja Belt (Fig. 1) is described as a lithodemic unit and its correlation with the other Peräpohja Belt units is an open question (Perttunen \& Hanski, 2003). It chiefly comprises quartzites, mica schists and partly mylonitic quartz-feldspar gneisses (op. cit.).

A basin inversion commenced shortly after the deposition of the Paakkola Group at the onset of the Svecofennian orogeny at c. $1.9 \mathrm{Ga}$. During this orogeny, the rocks underwent polyphase deformation and were metamorphosed chiefly under greenschist facies conditions though in the northern and eastern margins of the belt, the grade reached up to upper-amphibolite facies (Salonsaari, 1990; Lappalainen, 1995; Niiranen et al., 2003; Perttunen $\&$ Hanski, 2003). The first deformation phase, $\mathrm{D}_{1}$, produced recumbent isoclinal folds and pervasive layer-parallel schistosity $\left(S_{1}\right)$ by a N-Sdirected compression (Salonsaari, 1990; Lappalainen, 1995; Kyläkoski, 2004). Tight folds with EW-trending axial planes and crenulation cleavage were formed during $\mathrm{D}_{2}$ in a N-S compression. During $\mathrm{D}_{3}$, open folds with N-S trending axial planes, commonly without axial planar foliation, formed in an E-W compression. The few granitoidic and gabbroidic stocks and plutons of the c. 1.89 
Ga Haaparanta Series are coeval with $\mathrm{D}_{2}$ and give the minimum depositional age for the supracrustal rocks of the Peräpohja Belt (Lehtonen et al., 1998; Perttunen \& Vaasjoki, 2001).

\section{Samples and analytical methods}

Samples of the PFm were collected from drillcores and, at Petäjäskoski, from outcrops in, and boulders on, the channel banks. The locations of the drilling sites and the Petäjäkoski channel are shown in Fig. 1. The sampled drillcores originate from various previous exploration and bedrock mapping campaigns (e.g., Vartiainen, 1996; Rossi, 2000; Isomaa \& Sandgren, 2006; Lintinen, 2006; Vartiainen \& Salmirinne, 2009). Geochemical data and thin sections related to these investigations were also utilized in this study. The analyzed mica schist samples represent fine- and medium-grained (claystones and siltstones, respectively) laminae and layers as well as thinly laminated rhythmites (mudstones) containing both components (Fig. 4A). Only a few samples are available from the albite schists as the intense alteration and brecciation in the albitic strata hampered their sampling. Dolomite and quartzite samples were collected both from the micaceous and albitic strata.

For U-Pb zircon dating, a gabbroic sample (A2087) was picked from drillcore M52/2633/03/ R566 obtained from Kuusivaara (for the location, see Fig. 1). The intersected magmatic body represents a 90-m-thick, concordant mafic sill within the Petäjäskoski Formation. The sample has a metamorphic mineral paragenesis of actinolite, albite, magnetite and chlorite. Detrital zircon grains were dated from a quartzitic sample (A2089) that was collected from the Petäjäskoski channel in order to test the potential presence of zircon grains from Paleoproterozoic mafic igneous rocks among the detritus in the PFm metasediments. The U-Pb isotopic analyses were performed using the LA-MCICPMS technique at the Geological Survey of Finland in Espoo. The measurements were made using a $25 \mu \mathrm{m}$ spot size and GJ1 (609 Ma) and A1772 (2712 Ma) standards. The mineral separation and analytical techniques are more fully explained in Huhma et al. (2012).

The whole-rock analyses were performed by Labtium $\mathrm{Oy}$ in Finland (drillcore samples) and AcmeLabs in Canada (Petäjäskoski channel samples). Major elements were determined by the conventional XRF method using pressed powder pellets (Labtium Oy) and by ICP-OES after lithium metaborate/tetraborate fusion and dilute nitrite digestion (AcmeLabs). The XRF assays also included trace elements As, Ba, Bi, Ce, Cl, Cr, Cu, Ga, La, $\mathrm{Mo}, \mathrm{Nb}, \mathrm{Ni}, \mathrm{Pb}, \mathrm{Rb}, \mathrm{Sb}, \mathrm{Sc}, \mathrm{Sn}, \mathrm{Sr}$, Th, U, V, Y, Zn and $\mathrm{Zr}$ and the ICP-OES assays $\mathrm{Ba}, \mathrm{Be}, \mathrm{Co}, \mathrm{Cs}$, Ga, Hf, Nb, Ni, Rb, Sc, Sn, Sr, Ta, Th, U, V, W, Zr and $Y$ and rare-earth elements (REE). The REEs, $\mathrm{Zr}$, Co, Hf, Nb, Sc, Ta, Th, U, V, Y and Yb for the drillcore samples were determined by ICP-MS after total dissolution, and $\mathrm{C}$ and $\mathrm{S}$ were analyzed by a LECO analyzer. Loss of ignition (LOI) was determined only for the Petäjäskoski samples.

Approximately 100 polished thin sections were prepared in the laboratories of the Geological Survey of Finland and the Department of Geosciences, University of Oulu. Mineral analyses were performed at the Institute for Electron Optics (EOL, currently the Center of Microscopy and Nanotechnology), University of Oulu, using a JEOL JXA8200 microanalyzer with $15 \mathrm{kV}$ accelerating voltage and beam current of $15 \mathrm{nA}$. XRD determinations were conducted at EOL and were primarily focused on identification of miscellaneous phyllosilicates.

\section{Geology and mineralogy of the Petäjäskoski Formation}

\subsection{General features}

Well-preserved sedimentary structures and textures, which are described in more detail below, indicate that the Petäjäskoski Formation as a whole represents a metamorphosed sedimentogenic rock unit. With a stippled yellow symbol, the occurrence of the formation above the quartzites of the Palokivalo Formation is shown in the stratigraphic map of Fig. 1. The map also shows locations where the 
Petäjäskoski Formation has been penetrated by drillholes. Figure 3 displays the occurrence of the Petäjäskoski Formation at the type locality (Petäjäskoski channel) and its neighborhood based on airborne electromagnetic maps.

The presently available outcrop and drillcore observations do not allow a presentation of a detailed cross-section through the PFm. Half of the holes intersect the PFm at an undefined stratigraphic level and another intersect the contact between the Petäjäskoski Formation and the overlying Jouttiaapa Formation and extend, at best, $125 \mathrm{~m}$ down into the former without reaching the Palokivalo Formation. Except for dolomites that have been described from outcrops immediately below the Jouttiaapa Formation (Perttunen, 1991; Perttunen \& Hanski, 2003), there are no natural outcrops of the PFm rocks. The main reason for this is that the rocks are deeply weathered. The PFm strata are covered by a weathering crust tens of meters in thickness, which in turn is overlain by a thick overburden of quaternary till, glaciofluvial sand or peat bog. Unfortunately, also the outcrops in the Petäjäskoski channel banks are discontinuous and badly deteriorated after the 50 years of exposure to air and water. In addition, the rocks are intensely folded in this locality.

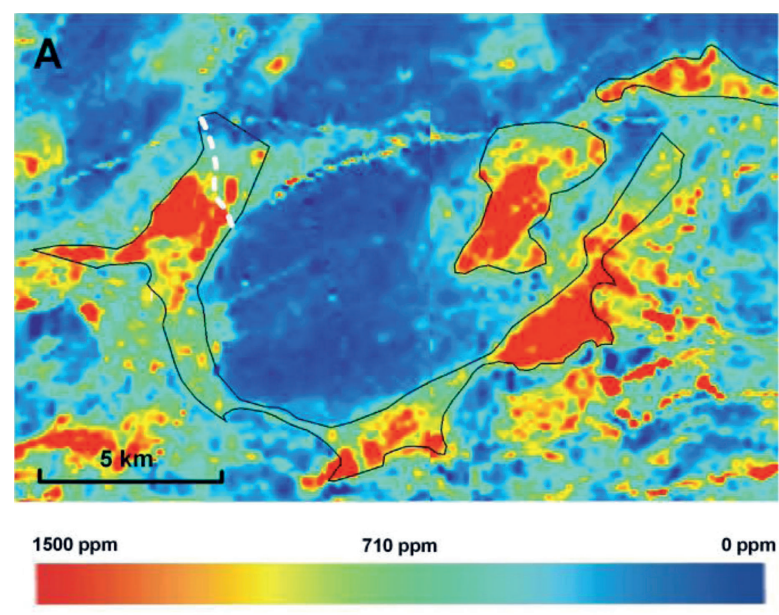

The weathering crust and the overlying wet overburden causes strong electromagnetic anomalies, which can be used to track the Petäjäskoski Formation in the subsurface by airborne geophysics: airborne electromagnetic in-phase and quadrature anomalies extending for tens of kilometers follow the unexposed strata between the Palokivalo and Jouttiaapa Formations (Fig. 3). The weathered PFm rocks display also low-gravity anomalies (Vartiainen \& Salmirinne, 2009). Whilst the drillcores do not provide complete sections through the succession, together with geophysical data they show that the PFm is basin-wide in extent and that its thickness can be estimated to be hundreds of meters. The upper contact with the Jouttiaapa Formation basalts is not exposed but is sharp based on drillcore data. The lower contact with the Palokivalo Formation is not exposed and has not been intersected by drilling

The bulk of the PFm is formed by two types of schists: micaceous and albitic. Sericitic and phlogopitic end-member types are observed among the mica-rich schists. These rocks have been intersected at most of the drilling sites and also occur in the Petäjäskoski channel (Fig. 1). Albitic schists are composed mainly of albite and hematite and have been recovered by drillholes at Lapioaapa and

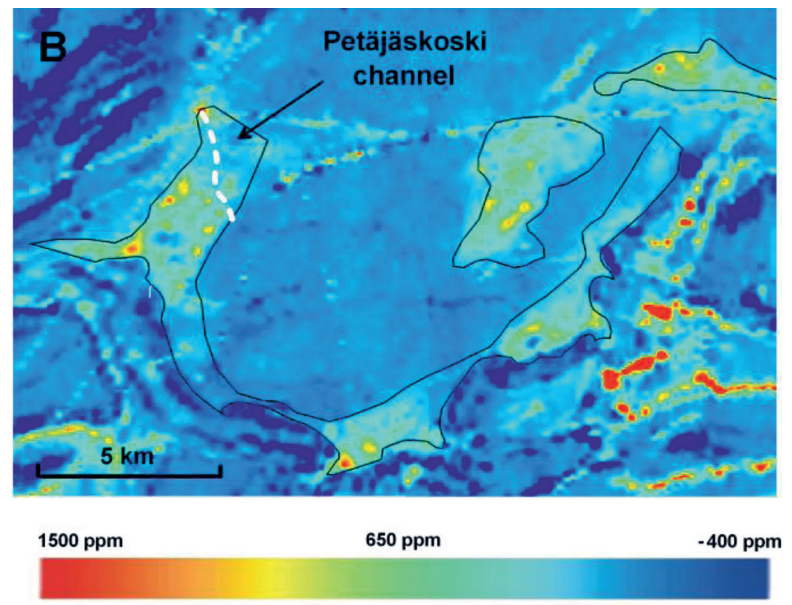

Fig. 3. Geophysical maps showing airborne electromagnetic A) quadrature (imaginary) and B) in-phase (real) anomalies of the area outlined in Fig. 1. The black lines mark the interpreted contacts of the Petäjäskoski Formation, and the dashed white line indicates the location of the Petäjäskoski channel. Geophysical data from the Geological Survey of Finland (Airo, 2005). 
Vammavaara. Disseminated hematite is conspicuous in the micaceous schists, and its presence is a diagnostic feature for the PFm in general. Quartzite and dolomite interbeds are common, but subordinate compared to the two major lithologies. In the albite-rich strata, matrix-supported breccias are ubiquitous.

Because of the coarsening of minerals and particularly clays during metamorphism, a grain size-based classification is not readily applicable for defining the original lithological features of the PFm siliciclastics. Therefore, assuming that the volumetric abundance of micas represents that of the original clayey material, the PFm siliciclastics are classified by the relative abundances of micas and quartz plus feldspars. The classification is in general agreement with the grain size variation.

The PFm mica schists constitute alternating fine-grained micaceous and micaceous-quartzose layers and laminae. With the mica contents reaching 90 vol.\%, the micaceous layers are classified as claystones and the micaceous-quartzose layers, with mica to quartz ratios of c. 50:50, as siltstones (cf. Friedman \& Sanders, 1978) (Figs. 4A, 4B, 6F). Similarly, with a matrix contents less than 10 vol.\%, the quartzites are referred to as sandstones (Figs. $8 \mathrm{~A}, \mathrm{~B})$. By analogy, dolomites are referred to as dolostones. The claystones and siltstones are collectively referred to as mudstones. As described below, the albite schists seem to possess similar structural, textural and geochemical characteristics to those of the mica schists; hence they are regarded as part of the siliciclastic succession.

The PFm rocks have been susceptible to deformation between the more competent quartzites and mafic volcanic rocks of the Palokivalo and Jouttiaapa Formations, respectively. The mica schists record structures of all folding events of the belt and are intensely foliated. The albitic strata have been folded in a similar fashion. The mica grains in the micaceous schists are aligned parallel to compositional layering and define the layer-parallel $S_{1}$ schistosity. Phlogopite also forms non-oriented poikiloblasts, which have been folded in the $\mathrm{F}_{2}$ and $\mathrm{F}_{3}$ events. No new mineral growth is observed in the axial surfaces of $\mathrm{F}_{2}$ or $\mathrm{F}_{3}$ folds, and hence the peak-metamorphic mineral assemblage was formed during $\mathrm{D}_{1}$ and the peak-metamorphic conditions prevailed beyond but concluded before $\mathrm{D}_{2}$.

Mafic sills within the PFm have been intersected by drilling at Kuusivaara, Viidanmaa and Lapioaapa. The sills are nondifferentiated and, in terms of mineralogy and geochemistry, differ from the c. 2.22 Ga layered sills intruding the underlying Palokivalo Formation (cf. Hanski et al., 2010).

\subsection{Lithological characteristics}

\subsubsection{Siliciclastics}

The micaceous schists (mudstones), which have been intersected at most drilling sites and also occur in the Petäjäskoski channel, form packages, up to a few meters in thickness, in which micaceous claystones alternate with micaceous-quartzose siltstones (Fig. 4A). The claystones form 1-mm- to $1-\mathrm{cm}$-thick laminae and layers and are finer-grained $(<50 \mu \mathrm{m})$ than the $1-\mathrm{mm}$ - to 3 -cm-thick, coarser $(-50-200 \mu \mathrm{m})$ siltstone laminae and layers. The laminae are typically massive and commonly equally thick, but the siltstone laminae may be discontinuous. Expressions like 'lenticular bedding with connected flat lenses' or 'wavy bedding' are applicable (cf. Reineck \& Wunderlich, 1968). In places where the claystone and siltstone layers are thicker, they tend to be graded and the siltstones tend to be coarser, more quartz-rich and discontinuous. Siltstones may also grade into claystones (Fig. 5A). Locally, the silt layers take a form of claystone-enveloped lenses that float in a clayey matrix. The bedding can be described as 'lenticular bedding with single flat lenses, or single thick lenses' depending on the length/height ratio of the lenses (Reineck \& Wunderlich, 1968). Loading of silt into claystone is also observed (Fig. 4C). Sericitic and phlogopitic end-member types of the mudstones cannot be distinguished macroscopically. Neither is the hematite dissemination readily detectable.

The lower portions of the red sandstone interbeds within the mudstone sequences are usually horizontally-bedded (Fig. 4C). Boundaries against 


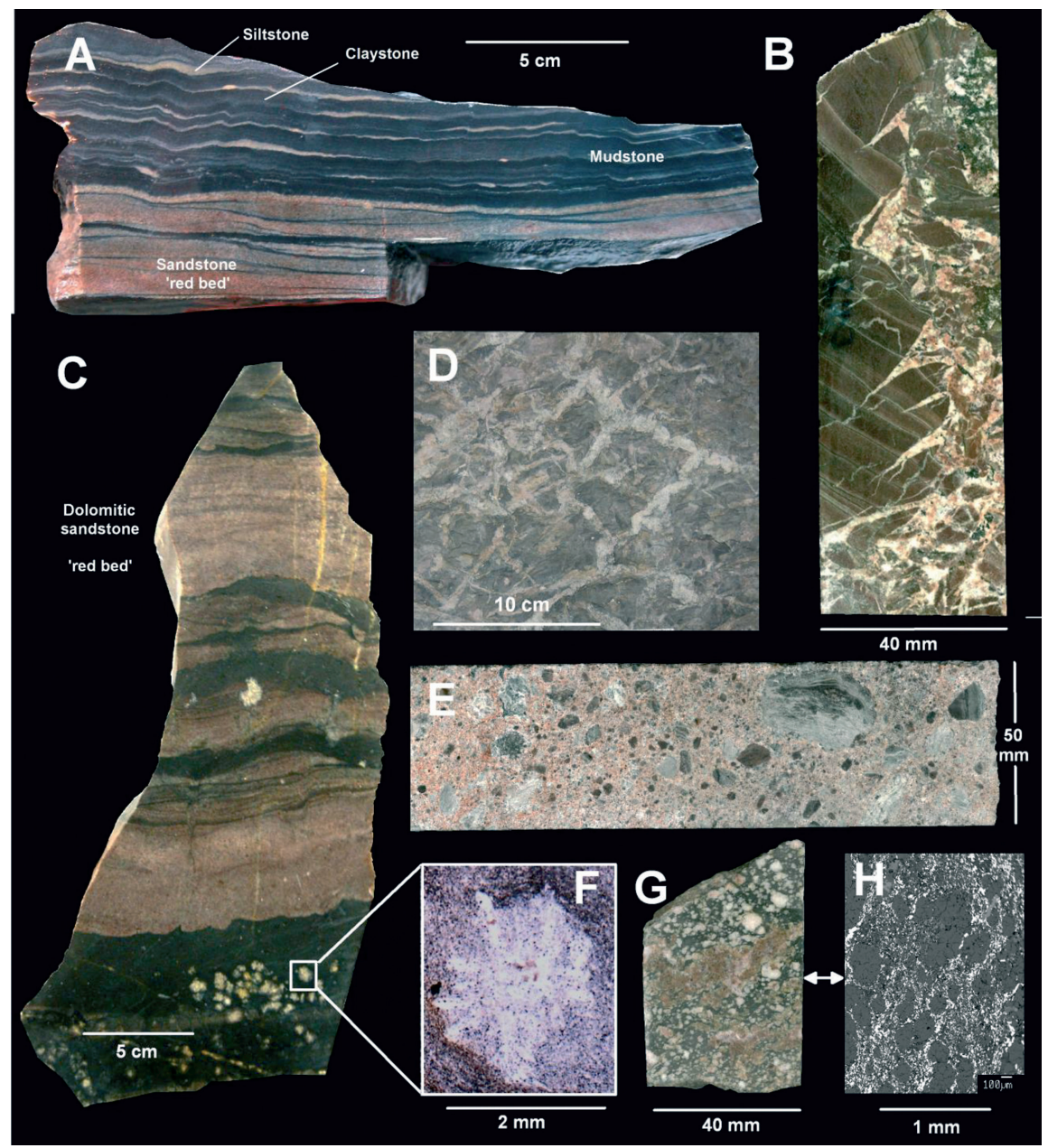

Fig. 4. Textural and structural characteristics of Petäjäskoski Formation mudstones and albite schists. A) Rhythmically alternating, gray, phlogopitic claystone laminae and yellowish, discontinuous siltstone laminae in the upper part of the sample. The lower part consists of claystone-draped, cross-bedded, red sandstone layers. Petäjäskoski. B) Graded albite schist brecciated by albite-microcline-talc-calcite veinlets (the same assemblage as in the breccia matrix of Fig. 4E). Viidanmaa. C) Red dolomitic sandstone with massive to horizontally bedded lower parts and cross-bedded, mud-draped upper parts. Some of the cross-beds dip in opposite directions. Load casts are observed against the blackish and nodular claystone layer. Petäjäskoski. D) Desiccation cracks in claystone. Petäjäskoski. E) Matrix-supported breccia. The clasts are composed of partly altered albite schist. Few quartzose clasts are observed, too. The matrix and replacing minerals include albite, microcline, talc and calcite, that is, the same mineral assemblage that brecciates the albite schist in Fig. 4B. Lapioaapa. F) Close-up view of Fig. 4C, showing a quartz-filled, radiating, layer-displacive nodule. G) Stratiform, albite-filled nodules in albite schist. Viidanmaa. H) Close-up back-scattered electron (BSE) image of the sample in Fig. G. The bright mineral is hematite.

mudstones are sharp and load casts are typical. In the upper parts of the red sandstone beds, crossbedded, undulating layers a few centimeters in thickness occur, which are separated by millimeterthick, massive to graded and locally discontinuous claystone drapes. The bedding can be described as flaser bedding (cf. Reineck \& Wunderlich, 1968).
Some overlying layers, separated by claystone drapes, dip in opposite directions. The red sandstones are overlain by mudstone rhythmites or thicker massiveappearing claystone layers (Figs. 4A, C). Dolomite beds may be present, too, but siltstones appear to be mostly lacking in these sequences. The thicker, whitish to grayish sandstone beds appear both 

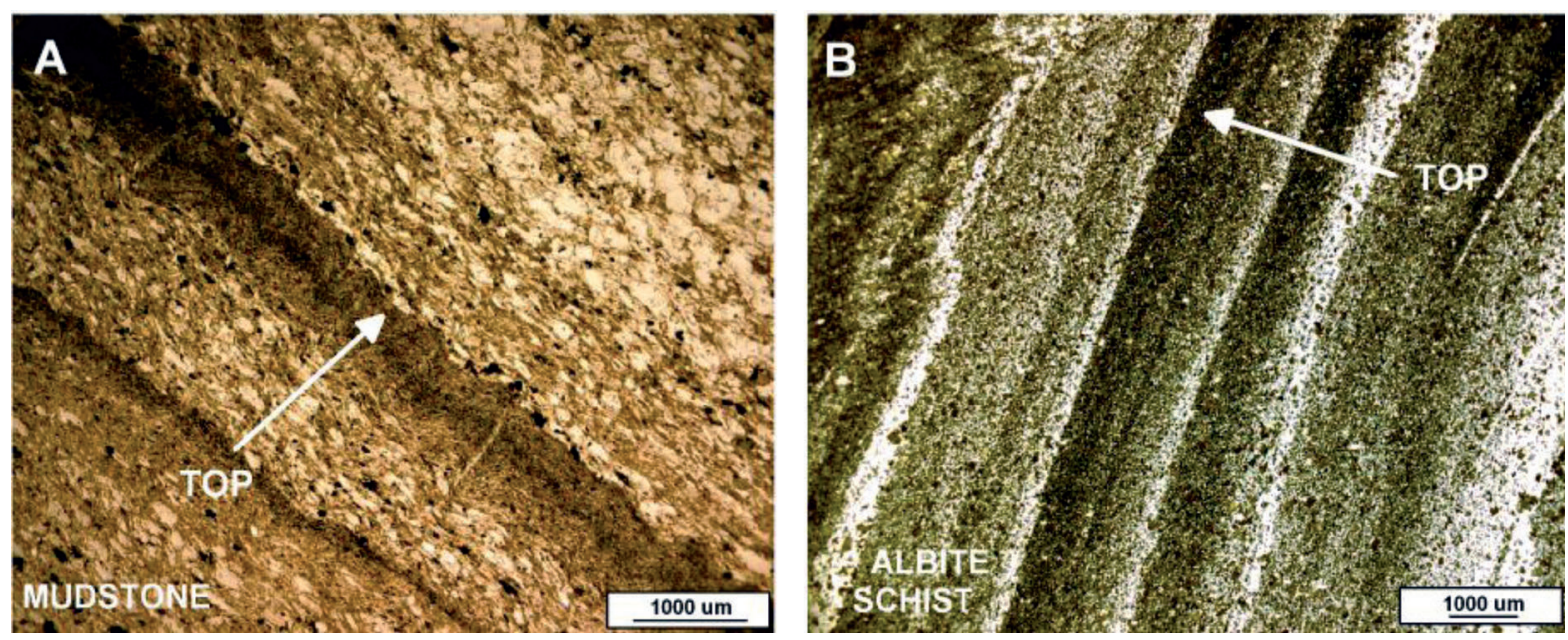

Fig. 5. Photomicrographs of graded mudstone (A) and albite schist (B). The opaque minerals are chiefly hematite. Hematite is coarser in the basal parts of the laminae and layers and becomes finer-grained and more abundant towards the upper parts.

horizontally-bedded and cross-bedded. Ripple marks were observed in bedding planes in the Petäjäskoski channel. Clastic textures in both sandstone types are commonly discernable (Figs. 5A, $8 \mathrm{~A}, \mathrm{~B})$.

Albitic schists, reddish to greenish-grayish in color, were intersected at Viidanmaa and Lapioaapa (Fig. 4B). They seem to display similar structures and textures as the micaceous schists; only the aluminous layers are nearly pervasively albitic, and the strata are intensely brecciated with the breccias (Fig. 4E) reaching thicknesses of more than $30 \mathrm{~m}$. Analogically to the mudstones, the millimeter-thick laminae in the albite schists appear to be massive and the thicker layers graded (Figs. 4B, 5B). Grading is marked by a grain size variation of albite, which is coarser in the basal parts of the layers, and by a concentration of hematite in the upper parts of the layers. As revealed by local hematite stripes in the upper layer boundaries, some of the layers appear cross-bedded, too.

Breccias of the albitic strata form successive, stratabound layers, up to tens of meters in thickness, bounded by undisturbed albite schist or quartzose sandstone interbeds. They are dominantly monomictic with the clasts being composed of adjacent albite schist. Quartzose clasts are observed locally in the Lapioaapa area where quartzites are more voluminous. The size of the clasts varies from c. 0.3 to $5 \mathrm{~cm}$ in diameter and the shape from angular to subrounded and rounded. They show no imbrication and are randomly oriented. At Viidanmaa, the matrix of the breccias is mainly composed of microcline, talc, chlorite and calcite. The same assemblage replaces and brecciates clasts and albite schists (Fig. 4B), and hence the mineral assemblage might not represent the original matrix material. At Lapioaapa, the matrix is composed of calcite and quartz for the most part.

The quartzite interbeds both in the micaceous and albitic strata occur as centimeters- to meterthick, Fe-oxide-pigmented, locally dolomitic beds (Fig. 4C) and as thicker ( -5 to $30 \mathrm{~m}$ ), whitishgrayish beds. Their grain size is in the range of $\sim 0.3-$ $1.5 \mathrm{~mm}$.

\subsubsection{Dolostones}

The dolostones described from outcrops immediately below the Jouttiaapa Formation basalts vary from yellowish-grayish, fine-grained and layered types to coarser, re-crystallized, whitish varieties with no apparent sedimentary structures (Perttunen, 1991; Perttunen \& Hanski, 2003). Stromatolites have been observed locally in these rocks (op. cit.). Perttunen (1991) correlated these 
exposed dolostones to those intersected by drilling a few meters below the Jouttiaapa Formation in the Jouttiaapa area. Re-examination of this drillcore (2544/-81/R-7), which represents the lower contact of the Jouttiaapa Formation and 50 metres of the underlying sedimentary rocks, revealed the presence of dissolved, vuggy dolostones interlayered with hematite-disseminated mica schists typical of the PFm. Karhu (1993) reported positive $\delta^{13} \mathrm{C}$ values ranging from +5.2 to $+10.6 \%$ for these dolostones, which are typical values of sedimentary carbonate rocks deposited during the Palaeoproterozoic marine carbon isotope excursion (Lomagundi-Jatuli event) between c. 2.2 and 2.06 Ga (Karhu, 2005; Melezhik et al., 2007).

Dolostones, commonly less than $10 \mathrm{~m}$ thick, have been intersected by drilling at Rumatmaat and Kuusivaara, and also at Viidanmaa (Fig. 1) where they are associated with albite schists. They are whitish to yellowish-brownish, fine-grained $(-<0.1-$ $0.3 \mathrm{~mm}$ ) and granoblastic in texture. Talc is the most common alteration product and occurs as individual flakes, in vein networks and patches commonly with more coarse-grained calcite. In some intensely talcaltered beds, almost all carbonate is calcite. At Rumatmaat and Kuusivaara, original bedding planes are not apparent but some beds are brecciated. The matrix in these crackle-type breccias is composed of phlogopite, tremolite and hematite. At Viidanmaa, the dolomite beds have millimeter- to centimeter-thick laminae composed of phlogopite and hematite. A bed containing magnesite was identified at Kuusivaara.

\section{Mineralogy of the siliciclastics}

The following gives description of the occurrence and chemical composition of the major and most important accessory minerals in the siliciclastic succession of the PFm. A detailed description is necessary in investigating the genesis of the rocks and the chemical and mineralogical alteration that they have experienced. Tables 1 and 2 list representative chemical compositions of various minerals.

\subsection{Quartz and carbonate}

Quartz is not encountered in the albite schists. Its amount in the claystones is variable, but it is always an accessory mineral and occurs as 10 - to $50-\mu \mathrm{m}$ sized, discrete, rounded to subhedral grains. Its grain size in the siltstones ranges from c. 0.05 to $0.2 \mathrm{~mm}$ and in the sandstones, from c. 0.1 to $1.5 \mathrm{~mm}$. In mature sandstones, granoblastic textures are common. Coarse, polycrystalline quartz aggregates in the sandstones, with the grains having irregular boundaries, might represent lithic fragments.

Granular dolomite, apparently of a detrital origin, is observed in varying amounts in the red sandstone layers of the Petäjäskoski samples (Fig. 4C). It is not observed in mudstones but occurs locally as cement together with calcite in quartzose sandstones. Calcite is locally observed in mudstones and is most likely secondary in origin.

\subsection{Phlogopite and sericite}

Phlogopite and sericite occur as layer-parallel flakes in the mudstones. In the claystones, the grain-size is less than $50 \mu \mathrm{m}$ and in the siltstones, c. $0.1-0.3$ mm (Figs. 5 and 6F). Non-oriented phlogopite poikiloblasts are also observed. These minerals are also common in interstitial spaces of the sandstones, and a small amount of phlogopite occurs in the albite schists. Under the microscope, they vary from colorless to brownish-yellowish. The normal pleochroism of phlogopite indicates that Fe is chiefly in the ferrous state. In the $\mathrm{K}$ - and Al-rich samples from Petäjäskoski, sericite forms very fine-grained, flaky to fan-like clusters overgrown by coarser phlogopite and sericite.

No compositional differences exist between the $\mathrm{S}_{0} / \mathrm{S}_{1}$-parallel phlogopites and those occurring as porphyroblasts. The compositions vary only little within a sample but show a wider, yet systematic variation between samples (Fig. 6). This implies rock-buffered compositions and is indicated by 1 ) an overall positive correlation between whole-rock and phlogopite $\mathrm{MgO}$ contents, 2) lower $\mathrm{K}_{2} \mathrm{O} / \mathrm{Al}_{2} \mathrm{O}_{3}$ and $\mathrm{Mg} /(\mathrm{Mg}+\mathrm{Fe})$ values of phlogopites in the sericitic mudstones compared to the phlogopitic 
Table 1. Average and representative chemical compositions of some of the major and accessory minerals of the PF siliciclastics.

\begin{tabular}{|c|c|c|c|c|c|c|c|c|c|c|c|c|}
\hline & $\begin{array}{l}\text { Phl } \\
\text { Avg. }\end{array}$ & $\mathrm{Phl}$ & $\mathrm{Phl}$ & $\begin{array}{c}\text { Seri } 1 \\
\text { Avg. }\end{array}$ & $\begin{array}{c}\text { Seri } 2 \\
\text { Avg. }\end{array}$ & $A b$ & $\mathrm{PI}$ & $\begin{array}{c}\text { Tourm } \\
\text { Core }\end{array}$ & $\operatorname{Rim}$ & Dol & Ap & $\mathrm{Hm}$ \\
\hline $\mathrm{SiO}_{2}$ & 40.30 & 39.06 & 41.14 & 47.58 & 47.36 & 68.94 & 56.47 & 36.79 & 36.09 & n.a. & n.a. & n.a. \\
\hline $\mathrm{TiO}_{2}^{2}$ & 0.99 & 0.97 & 0.71 & 0.55 & 0.56 & n.a. & 0.055 & 0.28 & 0.33 & n.a. & n.a. & 1.29 \\
\hline $\mathrm{Al}_{2} \mathrm{O}_{3}$ & 15.06 & 14.35 & 17.51 & 21.6 & 27.67 & 19.2 & 27.23 & 29.69 & 26.44 & n.a. & n.a. & 0.16 \\
\hline $\mathrm{Cr}_{2}^{2} \mathrm{O}_{3}^{3}$ & 0.03 & 0 & 0 & 0.02 & 0.004 & n.a. & n.a. & 0.02 & 0.04 & n.a. & n.a. & 0.08 \\
\hline $\mathrm{V}_{2} \mathrm{O}_{3}$ & 0.05 & 0.07 & 0.04 & 0.04 & n.a. & n.a. & n.a. & n.a. & n.a. & n.a. & n.a. & 0.011 \\
\hline $\mathrm{FeO}_{\text {tot }}$ & 3.22 & 2.27 & 1.36 & 3.14 & 3.28 & 0.072 & 0.26 & 4.37 & 5.89 & 0.06 & 0.08 & 88.67 \\
\hline $\mathrm{MnO}$ & 0.14 & 0.12 & 0.14 & 0.02 & 0.02 & 0.007 & 0.03 & 0.01 & 0.04 & 0.58 & 0.004 & 0.001 \\
\hline $\mathrm{MgO}$ & 22.88 & 22.31 & 24.03 & 3.19 & 3.06 & 0.023 & 0.105 & 10.18 & 10.38 & 19.4 & n.a. & 0.12 \\
\hline $\mathrm{CaO}$ & 0.04 & 0.001 & 0.04 & 0.04 & 0.04 & 0.02 & 10.07 & 1.38 & 1.98 & 27.21 & 54.91 & n.a. \\
\hline $\mathrm{BaO}$ & 0.05 & 0.09 & 0.05 & 0.18 & 0.15 & n.d. & 0.006 & 0.04 & 0.04 & n.a. & 0.003 & n.a. \\
\hline $\mathrm{Na}_{2} \mathrm{O}$ & 0.16 & 0.11 & 0.33 & 0.41 & 0.28 & 11.33 & 5.78 & 1.57 & 1.55 & n.a. & n.a. & 0.02 \\
\hline $\mathrm{K}_{2} \mathrm{O}$ & 9.27 & 9.55 & 8.13 & 9.99 & 9.94 & 0.11 & 0.16 & 0.09 & 0.13 & n.a. & n.a. & 0.03 \\
\hline $\mathrm{P}_{2} \mathrm{O}_{5}$ & n.a. & n.a. & n.a. & n.a. & n.a. & n.a. & n.a. & n.a. & n.a. & n.a. & 42.34 & 0.03 \\
\hline $\mathrm{ZnO}$ & 0.09 & 0.05 & 0.08 & 0.05 & 0.08 & 0.016 & 0.145 & n.a. & n.a. & n.a. & n.a. & 0.07 \\
\hline $\mathrm{NiO}$ & 0.04 & 0.00 & 0.04 & 0.02 & 0.02 & 0.009 & n.d. & n.a. & n.a. & n.a. & n.a. & n.a. \\
\hline $\mathrm{CuO}$ & 0.02 & 0 & 0 & 0.04 & 0.03 & 0.014 & 0.005 & n.a. & n.a. & n.a. & n.a. & 0.056 \\
\hline$F$ & 0.05 & 0 & 0 & n.a. & n.a. & n.a. & n.a. & n.a. & n.a. & n.a. & 2.04 & 0.34 \\
\hline $\mathrm{Cl}$ & 0.05 & 0.01 & 0.04 & 0.24 & 0.35 & n.a. & n.a. & 0.01 & 0.02 & n.a. & 0.32 & n.a. \\
\hline $\mathrm{B}_{2} \mathrm{O}_{3} *$ & n.a. & n.a. & n.a. & n.a. & n.a. & n.a. & n.a. & 10.53 & 10.19 & n.a. & n.a. & n.a. \\
\hline $\mathrm{H}_{2} \mathrm{O}^{*}$ & 4.10 & 3.99 & 4.27 & 3.93 & 4.15 & n.a. & n.a. & 3.63 & 3.51 & n.a. & 0.95 & n.a. \\
\hline $\mathrm{CO}_{2}$ & n.a. & n.a. & n.a. & n.a. & n.a. & n.a. & n.a. & n.a. & n.a. & 52.41 & n.a. & n.a. \\
\hline Total & 96.51 & 92.93 & 97.89 & 90.75 & 96.81 & 99.69 & 100.03 & 98.6 & 96.6 & 100 & 100.67 & 90.88 \\
\hline $\mathrm{Si}$ & 5.84 & 5.867 & 5.763 & 7.05 & 6.57 & 12.06 & 10.14 & 6.07 & 6.16 & n.a. & n.a. & n.a. \\
\hline $\mathrm{Al}$ & n.a. & n.a. & n.a. & n.a. & n.a. & 3.96 & 5.76 & n.a. & n.a. & n.a. & n.a. & n.a. \\
\hline $\mathrm{Al}^{\mathrm{IV}}$ & 2.16 & 2.133 & 2.237 & 0.95 & 1.43 & n.a. & n.a. & 0 & 0 & n.a. & n.a. & n.a. \\
\hline $\mathrm{Al}^{\mathrm{VI}}$ & 0.41 & 0.406 & 0.655 & 2.83 & 3.1 & n.a. & n.a. & 5.77 & 5.32 & n.a. & n.a. & n.a. \\
\hline $\mathrm{Ti}$ & 0.11 & 0.109 & 0.074 & 0.06 & 0.06 & n.a. & 0.0074 & 0.035 & 0.042 & n.a. & n.a. & n.a. \\
\hline $\mathrm{Cr}$ & 0.03 & 0 & 0 & 0.002 & 0.004 & n.a. & n.a. & 0.003 & 0.001 & n.a. & n.a. & n.a. \\
\hline $\mathrm{V}$ & 0.02 & 0.003 & 0.001 & 0.001 & 0.002 & n.a. & n.a. & n.a. & n.a. & n.a. & n.a. & n.a. \\
\hline $\mathrm{Fe}^{2+}$ & 0.39 & 0.285 & 0.159 & 0.39 & 0.38 & 0.01 & 0.038 & n.a. & n.a. & n.a. & 0.011 & n.a. \\
\hline $\mathrm{Fe}^{3+}$ & n.a. & n.a. & n.a. & n.a. & n.a. & n.a. & n.a. & 0.23 & 0.68 & n.a. & n.a. & n.a. \\
\hline$M n$ & 0.02 & 0.016 & 0.016 & 0.03 & 0.02 & n.a. & n.a. & 0.001 & 0.005 & n.a. & 0.006 & n.a. \\
\hline $\mathrm{Mg}$ & 4.94 & 4.994 & 5.018 & 0.71 & 0.63 & n.a. & n.a. & 2.5 & 2.64 & n.a. & & n.a. \\
\hline $\mathrm{Ca}$ & 0.06 & 0 & 0.006 & 0.01 & 0.01 & 0.003 & 1.94 & 0.24 & 0.36 & n.a. & 9.86 & n.a. \\
\hline $\mathrm{Ba}$ & 0.03 & 0.005 & 0.003 & 0 & 0 & n.a. & n.a. & 0 & 0 & n.a. & n.a. & n.a. \\
\hline $\mathrm{Na}$ & 0.05 & 0.031 & 0.089 & 0.12 & 0.08 & 3.84 & 2.02 & 0.5 & 0.51 & n.a. & n.a. & n.a. \\
\hline $\mathrm{K}$ & 1.71 & 1.828 & 1.453 & 1.89 & 1.76 & 0.02 & 0.04 & 0.02 & 0.03 & n.a. & n.a. & n.a. \\
\hline$P$ & n.a. & n.a. & n.a. & n.a. & n.a. & n.a. & n.a. & n.a. & n.a. & n.a. & 6.01 & n.a. \\
\hline$F$ & 0.23 & 0 & 0 & 0.11 & 0.15 & n.a. & n.a. & n.a. & n.a. & n.a. & 1.08 & n.a. \\
\hline $\mathrm{Cl}$ & 0.13 & 0.003 & 0.01 & 0 & 0 & n.a. & n.a. & 3En.a.04 & 0.0005 & n.a. & 0.09 & n.a. \\
\hline $\mathrm{OH}^{*}$ & 3.96 & 4.00 & 3.99 & 3.89 & 3.85 & n.a. & n.a. & 3.99 & 3.99 & n.a. & 1.06 & n.a. \\
\hline $\mathrm{Zn}$ & 0.01 & 0.005 & 0.009 & 0.005 & 0.009 & & 0.0192 & n.a. & n.a. & n.a. & n.a. & n.a. \\
\hline $\mathrm{Ni}$ & 0.005 & 0 & 0.004 & 0.002 & 0.002 & n.a. & n.a. & n.a. & n.a. & n.a. & n.a. & n.a. \\
\hline $\mathrm{Cu}$ & 0.002 & 0 & 0 & 0.004 & 0.003 & n.a. & n.a. & n.a. & n.a. & n.a. & n.a. & n.a. \\
\hline Sum & 19.65 & 19.68 & 19.49 & 18 & 18.02 & 19.89 & 19.99 & n.a. & n.a. & n.a. & n.a. & n.a. \\
\hline $\mathrm{mg} \#$ & 0.93 & 0.95 & 0.97 & 0.64 & 0.62 & n.a. & n.a. & 0.81 & 0.76 & n.a. & n.a. & n.a. \\
\hline
\end{tabular}

Phl: phlogopite, Seri 1: sericite, Aln.a.poor, Seri 2: sericite, Aln.a.rich, Ab: albite, Pl: plagioclase, Tourm: tourmaline, Dol: dolomite, Ap: apatite, Hm: hematite, Avg: average, n.a. not analyzed.

*: calculated. Fe for micas, albite, plagioclase and apatite is calculated as $\mathrm{Fe}^{2+}$. 
Table 2. Chemical compositions of miscellaneous phyllosilicates (Groups 1-4) and chlorite.

\begin{tabular}{|c|c|c|c|c|c|}
\hline & Group 1 & Group 2 & Group 3 & Group 4 & Chlorite \\
\hline $\mathrm{SiO}_{2}$ wt. $\%$ & 43.43 & 44.42 & 37.89 & 49.58 & 28.61 \\
\hline $\mathrm{TiO}_{2}^{2}$ & n.a. & n.a. & 0.88 & n.a. & 0.06 \\
\hline $\mathrm{Al}_{2} \mathrm{O}_{3}$ & 34.74 & 25.03 & 14.23 & 18.8 & 21.93 \\
\hline $\mathrm{Cr}_{2}^{2} \mathrm{O}_{3}^{3}$ & 0.08 & 0.02 & 0.01 & n.a. & 0.05 \\
\hline $\mathrm{FeO}_{\text {tot }}^{2}$ & 0.71 & 0.58 & 0.93 & 0.73 & 3.9 \\
\hline $\mathrm{MnO}^{\text {tot }}$ & 0.07 & 0.065 & 0.36 & 0.03 & 0.09 \\
\hline $\mathrm{MgO}$ & 4.34 & 16 & 29.47 & 6.61 & 30.02 \\
\hline $\mathrm{CaO}$ & 0.23 & 0.4 & 0.21 & 0.74 & 0.02 \\
\hline $\mathrm{BaO}$ & n.d. & 0.01 & 0.05 & 0.02 & 0.01 \\
\hline $\mathrm{Na}_{2} \mathrm{O}$ & 0.16 & 0.27 & 0.76 & 0.11 & 0.01 \\
\hline $\mathrm{K}_{2} \mathrm{O}$ & 0.27 & 0.99 & 1.09 & 4.14 & n.a. \\
\hline $\mathrm{Cl}^{2}$ & 0.11 & 0.09 & 0.06 & 0.12 & 0.01 \\
\hline Total & 84.1 & 87.9 & 85.9 & 80.9 & 84.71 \\
\hline $\mathrm{Si}$ & 6.12 & 6.15 & 5.6 & 7.45 & 5.45 \\
\hline $\mathrm{Al}^{\mathrm{IV}}$ & 1.88 & 1.85 & 2.4 & 0.51 & 2.46 \\
\hline $\mathrm{Al}^{\mathrm{Vl}}$ & 3.9 & 2.24 & 0.07 & 2.8 & 2.56 \\
\hline $\mathrm{Ti}$ & n.a. & n.a. & 0.09 & n.a. & 0.01 \\
\hline $\mathrm{Cr}$ & 0.004 & 0.003 & 0.002 & n.a. & 0.01 \\
\hline $\mathrm{Fe}^{2+*}$ & 0.84 & 0.68 & 0.12 & 0.09 & 0.56 \\
\hline $\mathrm{Fe}^{3+*}$ & n.a. & n.a. & n.a. & n.a. & 0.07 \\
\hline$M n$ & 0.01 & 0.01 & 0.04 & 0.003 & 0.02 \\
\hline $\mathrm{Mg}$ & 0.91 & 3.3 & 6.45 & 1.48 & 8.67 \\
\hline $\mathrm{Ca}$ & 0.03 & 0.06 & 0.03 & 0.12 & 0.004 \\
\hline $\mathrm{Na}$ & 0.04 & 0.07 & 0.22 & 0.03 & 0.01 \\
\hline K & 0.05 & 0.18 & 0.21 & 0.79 & n.a. \\
\hline $\mathrm{Cl}$ & 0.03 & 0.02 & 0.02 & 0.03 & 0.01 \\
\hline $\mathrm{OH}^{*}$ & 3.97 & 3.98 & 3.99 & 3.97 & 15.9 \\
\hline $\mathrm{mg} \#$ & 0.52 & 0.83 & 0.98 & 0.94 & 0.93 \\
\hline
\end{tabular}

n.a.: not analyzed, * calculated values. mg\#: $\mathrm{Mg} /\left(\mathrm{Mg}+\mathrm{Fe}^{2+}+\mathrm{Fe}^{3+}\right)$.

The formulas for phyllosilicates are calculated based on 24 oxygens $(\mathrm{O}, \mathrm{OH})$ and that of chlorites on $28 \mathrm{oxygens}(\mathrm{O}, \mathrm{OH})$. $\mathrm{Fe}^{2+} / \mathrm{Fe}^{3+}$ and $\mathrm{OH}$ for chlorite are calculated by assuming full site occupancy.

mudstones, and 3) the fact that phlogopites at Rumatmaat, where upper greenschist facies conditions were reached, show lower $\mathrm{Mg} /(\mathrm{Mg}+\mathrm{Fe})$ values apparently reflecting consumption of $\mathrm{Mg}$ by the formation of tremolite-actinolite. Phlogopites with high $\mathrm{K}_{2} \mathrm{O} / \mathrm{Al}_{2} \mathrm{O}_{3}$ ratios $(\rightarrow 0.8)$ are associated with secondary microcline, whereas the decrease in this ratio relates to chloritization of phlogopite. Chloritization of phlogopite is common, for example, at Kuusivaara (Fig. 6C) and is related to retrograde and/or hydrothermal alteration processes.

In terms of their $\mathrm{Al}_{2} \mathrm{O}_{3}$ contents, two types of sericite can be distinguished. That with lower $\mathrm{Al}_{2} \mathrm{O}_{3}$ contents $(-21$ wt.\%) is typically, but not systematically, fine-grained and overgrown by phlogopite or the second, coarser sericite type, which is higher in $\mathrm{Al}_{2} \mathrm{O}_{3}(-27$ wt.\%). Both sericite types have fairly high contents of $\mathrm{FeO}$ and $\mathrm{MgO}$ (3.2 and 3.7 wt. $\%$ in average, respectively), and their XRD patterns match best with that of phengite.

The $\mathrm{F}$ and $\mathrm{Cl}$ contents typically are similar in the sericites and phlogopites. When above the detection limit, the $\mathrm{Cl}$ contents typically range between 200 and 1000 ppm (maximum 7800 ppm) and the F contents between 400 and 6000 ppm. In one sample, phlogopite grains yielded F contents as high as $2.1-2.8 \mathrm{wt} . \%$.

Given the maximum and average $\mathrm{BaO}$ contents 

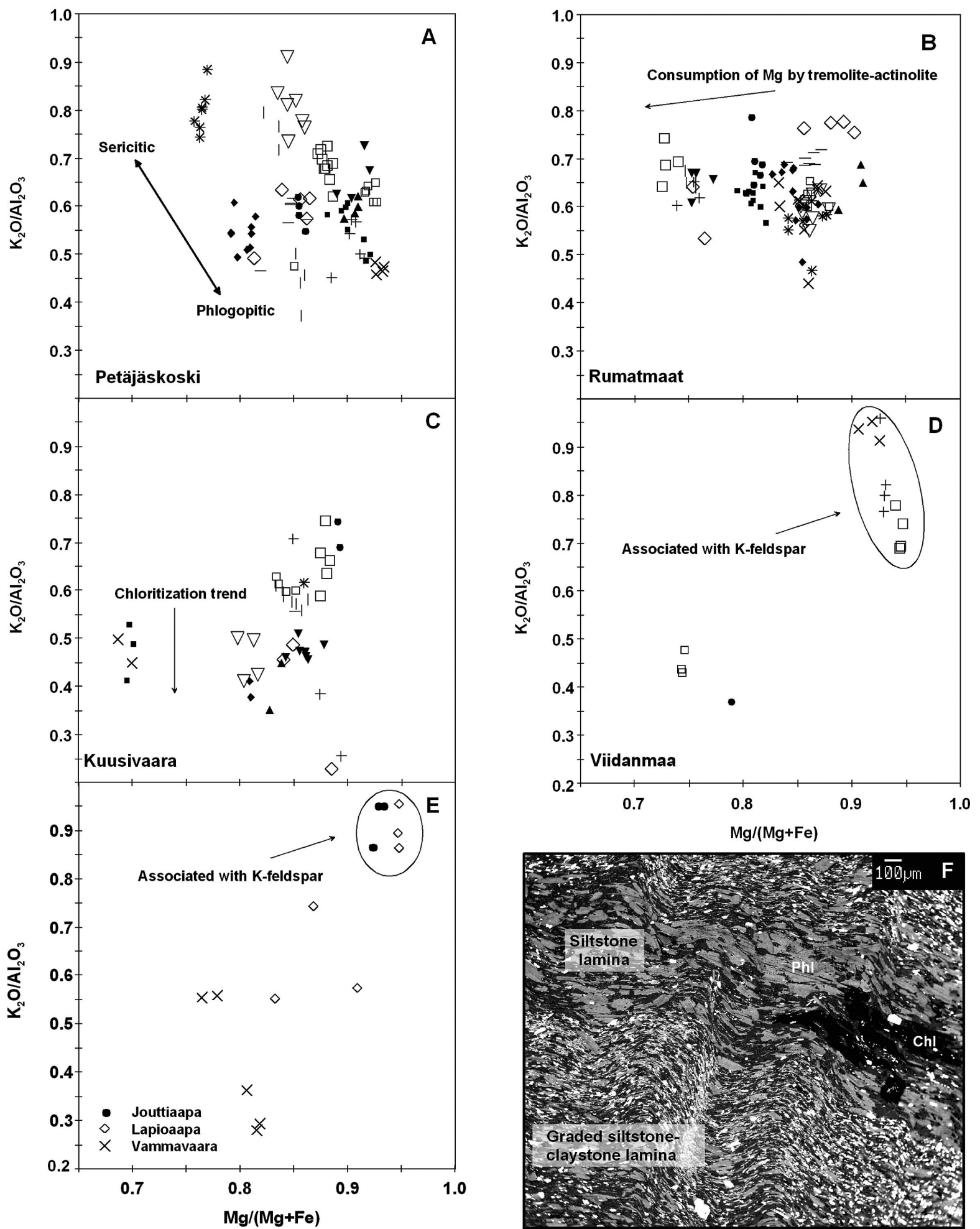

Fig. 6. $\mathrm{K}_{2} \mathrm{O} / \mathrm{Al}_{2} \mathrm{O}_{3}$ vs. $\mathrm{Mg} /(\mathrm{Mg}+\mathrm{Fe})$ diagrams (A-E) for phlogopite from the Petäjäskoski Formation. The symbols in Figs. A-D represent different samples from a given locality. F) BSE image showing phogopite in claystone-siltstone from Petäjäskoski. Phlogopite grains are folded $\left(F_{2}\right.$ folding) and coarser in siltstone. The bright mineral is hematite. Phl = phlogopite, $\mathrm{Chl}=$ chlorite. 
of 0.4 and 0.1 wt.\%, respectively, the sericites are fairly $\mathrm{Ba}$-rich. The $\mathrm{BaO}$ contents of phlogopite vary from below the detection limit to c. $0.3 \mathrm{wt} . \%$. The differences in the $\mathrm{BaO}$ contents are reflected in the bulk chemistry of the phlogopitic and sericitic schists (Table 3).

\subsection{Other phyllosilicates and chlorite}

Fibrous to flaky mineral clusters occur between mica grains in the mudstones and in intraclast spaces of the sandstones (Fig. 7D). As these miscellaneous phyllosilicates are overgrown by metamorphic potassic micas, they could represent primary clay minerals. They are Mg-rich and Fe-poor and have $\mathrm{SiO}_{2}$ contents $(-35 \mathrm{wt} . \%)$ higher than those in chlorites. Low oxide totals ( $-80-90 \%)$ suggest fairly high water contents. Naming the phyllosilicates by XRD failed for many reasons but mainly because of their modal abundance, which is too low for them to be sufficiently filtered out from the XRD graphs, and their compositional variability.

Based on the $\mathrm{SiO}_{2}, \mathrm{MgO}$ and $\mathrm{Al}_{2} \mathrm{O}_{3}$ contents, four groups of phyllosilicates are distinguished (Table 1). Groups 1, 2 and 3 are transitional: $\mathrm{SiO}_{2}$ and $\mathrm{Al}_{2} \mathrm{O}_{3}$ (Fig. 7A) display a strong positive correlation ( $\mathrm{r}$ 0.71), whereas a strong negative correlation is found between $\mathrm{MgO}$ and $\mathrm{Al}_{2} \mathrm{O}_{3}(\mathrm{r}$ 0.83 , Fig. $7 \mathrm{~B}$ ) and slightly weaker between $\mathrm{SiO}_{2}$ and $\mathrm{MgO}(\mathrm{r}-0.59)$. Correlations between other major elements are not as clear, but noteworthy is the positive correlation between $\mathrm{Na}_{2} \mathrm{O}$ and $\mathrm{Cl}(\mathrm{r}$ 0.69) with their concentrations ranging from below the detection limit to 2.3 and $1 \mathrm{wt} . \%$, respectively. Group 4 phyllosilicates are distinct from the others because of their higher $\mathrm{SiO}_{2}$ contents.

The Group 1 phyllosilicates are high in $\mathrm{Al}_{2} \mathrm{O}_{3}$ (33-38 wt.\%) and $\mathrm{SiO}_{2}(40-48$ wt.\%) and have low to moderate contents of $\mathrm{MgO}(1-10 \mathrm{wt} . \%)$ and low contents of $\mathrm{FeO}_{\text {tot }}$ and $\mathrm{K}_{2} \mathrm{O}$ (up to c. 1 and 1.5 wt. $\%$, respectively). The high $\mathrm{Al}_{2} \mathrm{O}_{3}$ contents suggest the presence of minerals of the kaolinite group. Kaolinite and dickite were identified by XRD from a few samples.

Group 2 phyllosilicates are transitional to Group
1 but are separated from the latter by their lower $\mathrm{Al}_{2} \mathrm{O}_{3}(-20-28$ wt.\%) and higher $\mathrm{MgO}$ contents $\left(-10-18\right.$ wt.\%), while the $\mathrm{SiO}_{2}, \mathrm{FeO}_{\text {tot }}$ and $\mathrm{K}_{2} \mathrm{O}$ contents are comparable. Analogs for their compositions can be found from the montmorillonite (smectite) group minerals.

Group 3 is transitional to Group 2. Compared to the latter, it shows lower $\mathrm{Al}_{2} \mathrm{O}_{3}$ (13-19 wt.\%) and $\mathrm{SiO}_{2}$ (37-40 wt.\%) but distinctively higher $\mathrm{MgO}$ ( -28 wt.\%). These compositions are close to those of chlorites though the $\mathrm{SiO}_{2}$ contents are still high.

Group 4 phyllosilicates show high $\mathrm{SiO}_{2}(48-53$ wt.\%) and low $\mathrm{FeO}_{\text {tot }}$ contents ( $<1.5$ wt.\%). The $\mathrm{MgO}$ contents are intermediate between those of Groups 1 and 2 and vary widely ( $-4-20$ wt.\%). The $\mathrm{Al}_{2} \mathrm{O}_{3}$ contents vary between $-17-25 \mathrm{wt} . \%$ and the $\mathrm{K}_{2} \mathrm{O}$ contents are the highest (1.5-4.5 wt.\%). The high $\mathrm{K}_{2} \mathrm{O}$ contents and the wide variation in $\mathrm{MgO}$ may indicate the presence of illite-vermiculite mixtures. Notable is also the partial overlap with Group 2 on the $\mathrm{Al}_{2} \mathrm{O}_{3}-\mathrm{MgO}$ and $\mathrm{Al}_{2} \mathrm{O}_{3}-\mathrm{K}_{2} \mathrm{O}$ plots (Figs. 7A, C). Group 4 as a whole records the highest $\mathrm{Na}$ contents (up to $3.5 \mathrm{wt} \%$ ).

$\mathrm{Mg}$-rich chlorites with c. 30 wt. $\%$ of $\mathrm{MgO}$ and $4 \mathrm{wt} . \%$ of $\mathrm{FeO}_{\text {tot }}$ are observed in some of the boulder samples collected from Petäjäskoski (Fig. 6F, Table 2). These chlorites seem to have not formed by retrograde alteration of phlogopite nor has the sample any evidence for hydrothermal alteration (as at Kuusivaara, for example).

\subsection{Plagioclase and albite}

In the mudstones, calcic plagioclase is an accessory mineral or, more commonly, not found at all. It has not been observed in the albite schists. In the siltstones and sandstones, it is more abundant, but in general not plentiful either. The anorthite content of plagioclase is typically between $\mathrm{An}_{25}$ and $\mathrm{An}_{60}$ mol.-\% (oligoclase-labradorite). Local poikiloblastic grains with $\mathrm{An}_{90}$ (bytownite) and zoned grains with Al-Ca-richer rims imply metamorphic re-crystallisation and some addition of $\mathrm{Ca}$.

The amount of albite in the albite schists reaches 90 vol. \%, and its composition is close to pure albite 
Table 3. Major and trace element compositions of sedimentary rocks from the Petäjäskoski Formation (PFm) and mafic sills intruding the PFm.

\begin{tabular}{|c|c|c|c|c|c|c|c|c|c|c|c|c|}
\hline & 1 & 2 & 3 & 4 & 5 & 6 & 7 & 8 & 9 & 10 & 11 & 12 \\
\hline $\mathrm{SiO}_{2}$ & 55.1 & 45.1 & 50.3 & 47.2 & 68.5 & 58.5 & 87.6 & 42.2 & 26.8 & 3.49 & 49.2 & 48.2 \\
\hline $\mathrm{TiO}_{2}^{2}$ & 1.13 & 1.31 & 1.46 & 1.23 & 0.5 & 1.12 & 0.09 & 0.27 & 0.25 & 0.04 & 1.16 & 1.12 \\
\hline $\mathrm{Al}_{2} \mathrm{O}_{3}$ & 16.8 & 23 & 15.3 & 19.5 & 12.3 & 16.5 & 4.02 & 7.07 & 4.92 & 0.57 & 14.9 & 14.9 \\
\hline FeOtot & 10.6 & 15.3 & 13.7 & 13.6 & 4.41 & 10.4 & 0.91 & 2.02 & 1.97 & 0.17 & 12.2 & 12.7 \\
\hline $\mathrm{MnO}$ & 0.05 & 0.02 & 0.08 & 0.03 & 0.02 & $<0.01$ & 0.03 & 0.27 & 0.43 & 0.35 & 0.23 & 0.21 \\
\hline $\mathrm{MgO}$ & 9.47 & 4.03 & 7.64 & 4.8 & 6.28 & 1.4 & 2.44 & 11.3 & 14.5 & 22.3 & 9.07 & 7.52 \\
\hline $\mathrm{CaO}$ & 0.14 & 0.19 & 1.85 & 0.2 & 0.22 & 0.25 & 1.27 & 12.8 & 19.8 & 28.7 & 6.45 & 8.88 \\
\hline $\mathrm{Na}_{2} \mathrm{O}$ & $<0.01$ & 0.16 & 2.1 & 0.23 & 2.47 & 10.1 & $<0.01$ & 2.0 & 2.25 & $<0.01$ & 2.91 & 2.63 \\
\hline $\mathrm{K}_{2} \mathrm{O}$ & 4.92 & 8.61 & 3.48 & 7.5 & 4.22 & 0.27 & 1.21 & 0.79 & 0.15 & 0.23 & 1.59 & 1.04 \\
\hline $\mathrm{P}_{2}^{2} \mathrm{O}_{5}$ & 0.11 & 0.14 & 0.17 & 0.12 & 0.11 & 0.03 & 0.06 & 0.09 & 0.05 & 0.02 & 0.08 & 0.09 \\
\hline $\mathrm{CO}_{2}$ & 0.1 & 0.13 & n.a. & n.a. & 0.09 & 0.28 & 0.89 & 19.6 & 29.2 & 43.9 & n.a. & n.a. \\
\hline $\mathrm{S}^{2}$ & $<0.01$ & $<0.01$ & $<0.02$ & 0.03 & 0.01 & $<0.01$ & $<0.01$ & $<0.02$ & $<0.02$ & $<0.01$ & 0.05 & 0.08 \\
\hline $\mathrm{Cl}$ & 0.01 & $<0.01$ & n.a. & n.a. & $<0.01$ & $<0.01$ & 0.01 & n.a. & n.a. & 0.01 & n.a. & 0.01 \\
\hline LOI & n.a. & n.a. & 2.1 & 3.8 & n.a. & n.a. & n.a. & 20.7 & 28.5 & n.a. & n.a. & n.a. \\
\hline Total & 98.5 & 98 & 98.2 & 98.2 & 99.1 & 98.8 & 98.5 & 99.5 & 99.6 & 99.8 & 97.8 & 97.4 \\
\hline $\mathrm{Cr}$ & 172 & 279 & 198 & 192 & 88 & 148 & n.a. & n.a. & n.a. & n.a. & 231 & 277 \\
\hline $\mathrm{Ni}$ & 107 & 74 & 96 & 87 & 115 & 43 & n.a. & 39 & $<20$ & 20 & 112 & 111 \\
\hline Co & 22 & n.a. & 37.6 & 19.2 & n.a. & 6.9 & n.a. & 17.4 & 11.5 & n.a. & 48 & n.a. \\
\hline V & n.a. & 274 & 281 & 277 & 130 & 257 & 32 & n.a. & n.a. & n.a. & 304 & 339 \\
\hline Sc & 37.7 & n.a. & 37 & 40 & n.a. & 18.5 & 3 & n.a. & n.a. & n.a. & 44.8 & 44.8 \\
\hline $\mathrm{Ba}$ & 311 & 2391 & 427 & 1600 & 412 & 26 & 246 & 69 & 17 & 30 & 726 & 109 \\
\hline $\mathrm{Sr}$ & $<10$ & $<10$ & 35.7 & 11.1 & $<10$ & $<10$ & 21 & 88.7 & 123 & 172 & n.a. & 117 \\
\hline $\mathrm{Rb}$ & 144 & 211 & 88 & 178 & 10 & 8.5 & 35 & n.a. & n.a. & n.a. & 33 & 34 \\
\hline $\mathrm{Cu}$ & $<20$ & $<20$ & n.a. & n.a. & $<20$ & $<20$ & $<20$ & n.a. & n.a. & n.a. & 152 & 125 \\
\hline $\mathrm{Zn}$ & 37 & $<20$ & n.a. & n.a. & 44 & 30 & n.a. & n.a. & n.a. & 40 & 91 & 99 \\
\hline $\mathrm{Zr}$ & 84 & 152 & 137 & 117 & 120 & 154 & 86 & n.a. & n.a. & n.a. & 49 & 66 \\
\hline $\mathrm{Ta}$ & 0.32 & n.a. & 0.5 & 0.7 & n.a. & 0.43 & n.a. & n.a. & n.a. & n.a. & 0.18 & n.a. \\
\hline $\mathrm{Nb}$ & 5.19 & n.a. & 7.6 & 8.3 & n.a. & 6.57 & n.a. & n.a. & n.a. & n.a. & 3.77 & n.a. \\
\hline Th & 7.97 & n.a. & 6.4 & 11.4 & n.a. & 10.1 & 4.59 & n.a. & n.a. & n.a. & 0.12 & n.a. \\
\hline$U$ & 2.21 & n.a. & 2.4 & 1.9 & n.a. & 1.18 & 0.89 & n.a. & n.a. & n.a. & 0.15 & n.a. \\
\hline Y & 23.8 & n.a. & 30.6 & 27.8 & n.a. & 20.8 & 9.88 & n.a. & n.a. & 10 & 22.6 & n.a. \\
\hline La & 23.9 & n.a. & 18 & 33.6 & n.a. & 24.7 & 6.75 & 17.9 & 7.1 & n.a. & 3.74 & 3.48 \\
\hline $\mathrm{Ce}$ & 46.8 & n.a. & 41 & 65.9 & n.a. & 50.5 & 13.2 & 38.6 & 13.7 & n.a. & 9.79 & 9.36 \\
\hline $\mathrm{Pr}$ & 5.4 & n.a. & 4.57 & 7.56 & n.a. & 5.59 & 1.43 & 4.85 & 1.77 & n.a. & 1.44 & 1.44 \\
\hline $\mathrm{Nd}$ & 21.8 & n.a. & 17.6 & 28.9 & n.a. & 21.2 & 6.93 & 19.2 & 7.3 & n.a. & 7.76 & 7.21 \\
\hline $\mathrm{Sm}$ & 4.4 & n.a. & 4.64 & 5.92 & n.a. & 3.74 & 1.56 & 4.37 & 1.94 & n.a. & 2.47 & 2.28 \\
\hline Eu & 1.1 & n.a. & 1.38 & 1.6 & n.a. & 0.91 & 0.28 & 0.94 & 0.61 & n.a. & 0.89 & 0.91 \\
\hline Gd & 4.9 & n.a. & 5.51 & 5.78 & n.a. & 3.96 & 1.84 & 3.81 & 2.3 & n.a. & 3.50 & 2.92 \\
\hline $\mathrm{Tb}$ & 0.76 & n.a. & 0.96 & 0.96 & n.a. & 0.61 & 0.24 & 0.63 & 0.38 & n.a. & 0.59 & 0.58 \\
\hline Dy & 4.4 & n.a. & 5.37 & 5.44 & n.a. & 3.51 & 1.68 & 3.44 & 2.23 & n.a. & 3.89 & 3.81 \\
\hline Ho & 0.87 & n.a. & 1.13 & 1.03 & n.a. & 0.8 & 0.34 & 0.66 & 0.43 & n.a. & 0.82 & 0.80 \\
\hline $\mathrm{Er}$ & 2.5 & n.a. & 3.25 & 2.95 & n.a. & 2.31 & 1.02 & 1.91 & 1.16 & n.a. & 2.41 & 2.33 \\
\hline $\mathrm{Tm}$ & 0.33 & n.a. & 0.52 & 0.5 & n.a. & 0.34 & 0.15 & 0.26 & 0.17 & n.a. & 0.35 & 0.33 \\
\hline $\mathrm{Yb}$ & 2.3 & n.a. & 3.31 & 3.22 & n.a. & 2.47 & 0.88 & 1.79 & 1.1 & n.a. & 2.33 & 2.19 \\
\hline Lu & 0.31 & n.a. & 0.48 & 0.46 & n.a. & 0.33 & 0.14 & 0.25 & 0.16 & n.a. & 0.35 & 0.33 \\
\hline
\end{tabular}

1) Phlogopitic claystone, Kuusivaara; 2) sericitic claystone, Petäjäskoski; 3) phlogopitic mudstone rhythmite, Petäjäskoski; 4) sericitic mudstone rhythmite, Petäjäskoski; 5) phlogopitic siltstone, Petäjäskoski; 6) albite schist, Viidanmaa; 7) gray sandstone, Kuusivaara; 8) red dolomitic sandstone, Petäjäskoski; 9) red dolomitic sandstone; 10) dolomite, Rumatmaat; 11) mafic sill, Kuusivaara, average of 12 samples; 12) mafic dike, Kätkävaara, average of 4 samples (data from Perttunen and Hanski, 2003). 

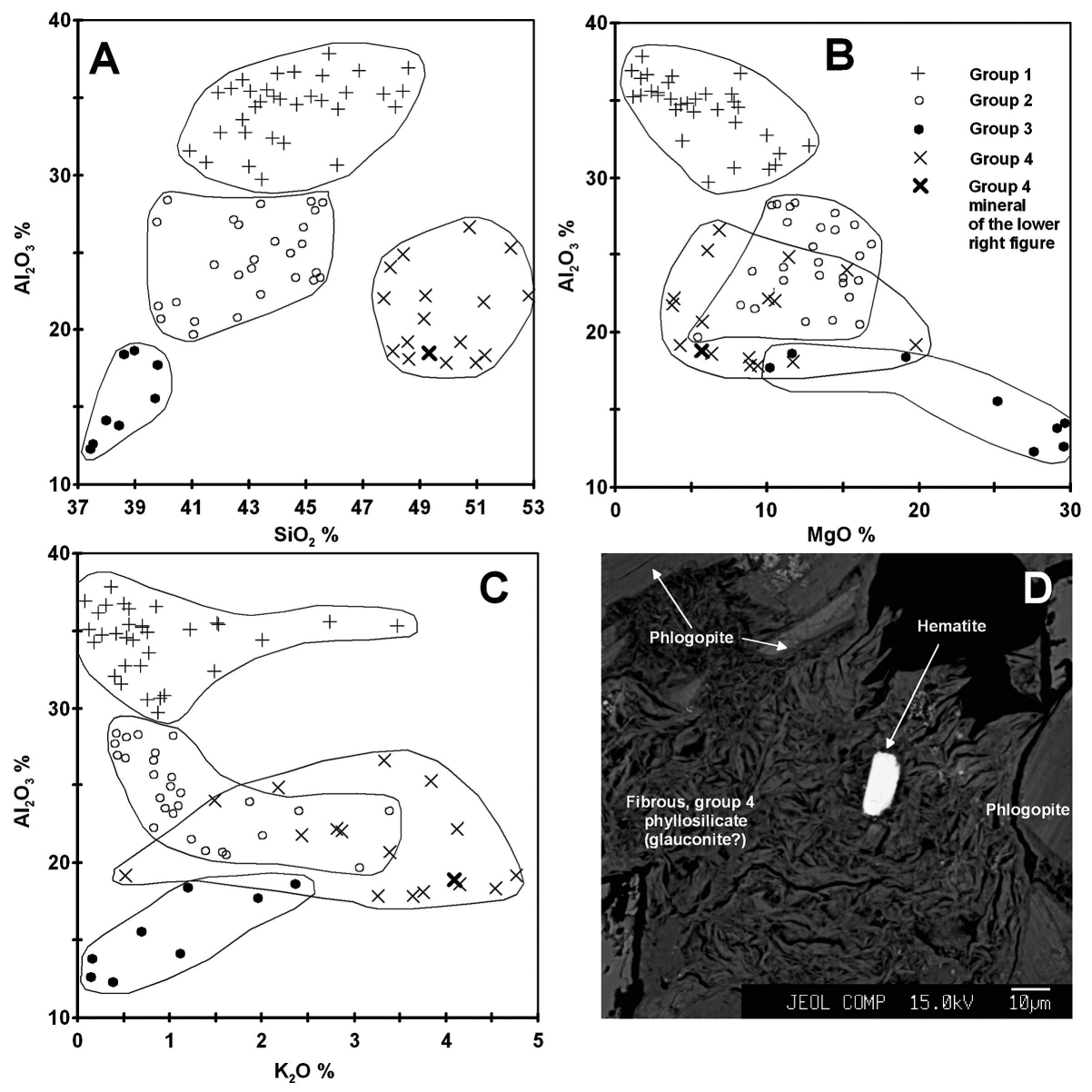

Fig. 7. Bivariate plots (Wt.\%) for miscellaneous phyllosilicates $(A-C)$. See legend in B. D) shows an example of Group 4 phyllosilicate between phlogopite grains (BSE image, Kuusivaara, analysis 4 in Table 3).

(averaging $A n_{01}$ ). The grains are coarser in the basal parts of layers and laminae (Fig. 8C) and typically form fine-grained, granoblastic mosaics that enclose or encircle hematite. In the mudstones, albite occurs as discrete grains.

\subsection{Hematite and rutile}

Both the mudstones and albite schists contain abundant disseminated, fine-grained $(<<100 \mu \mathrm{m})$ hematite (Figs. 5 and 8). This mineral is diagnostic for the PFm throughout the whole sedimentary basin. Because of its fine grain size, hematite is not readily detectable macroscopically. Reflective-light microscopy and BSE images show that the hematite grains are typically subhedral and homogenous (Fig. $8 D$ ), though in near surface samples, they have partly altered to goethite.
Hematite is distinctively concentrated in the claystones where its grain size is usually less than 50 $\mu \mathrm{m}$ as measured along their $S_{0} / S_{1}$-parallel long axis (Figs. 5 and 8). The amount is substantially smaller in the siltstones where the grains are either systematically finer or coarser compared to the adjacent claystone layers. Virtually no hematite exists in the whitish-grayish sandstone layers. In thinner, red sandstone layers, hematite is observed infrequently and is generally relatively coarse-grained (0.05-0.2 $\mathrm{mm})$.

In individual claystone layers, hematite is evenly distributed (Fig. 8B) but in layers where the basal portions are silty and upper portions clayey, hematite grades both in terms of amount and size, so that in the lower parts of the layers, hematite is usually coarser but less abundant (Figs. 4A, 5A, 6F). Similar distribution is observed in the albite schists: in 

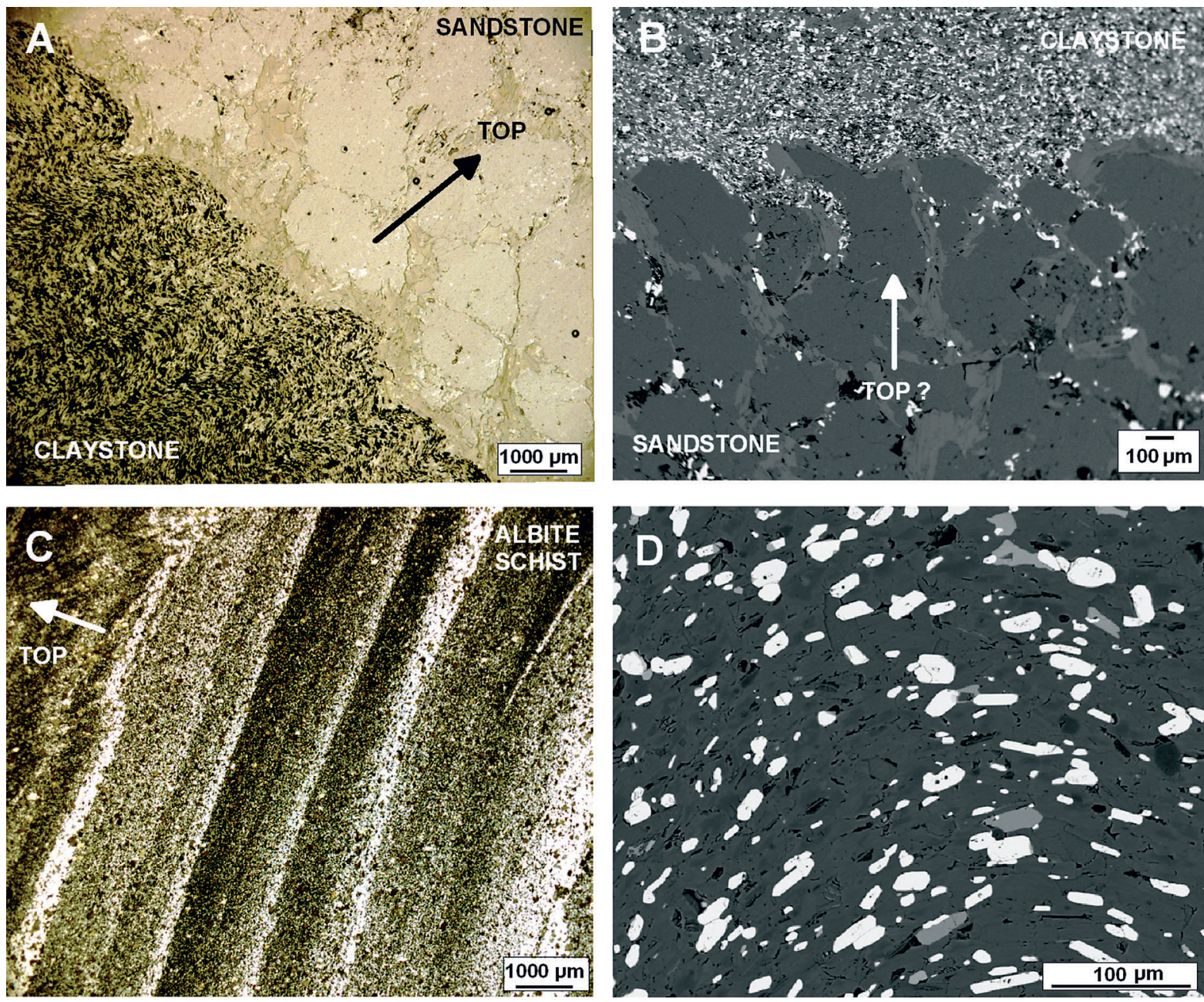

Fig. 8. Examples of occurrences of hematite (and rutile) in PFm siliciclastics. A) Photomicrograph of a contact between sandstone and claystone. Hematite is concentrated in the claystone. Kuusivaara. B) BSE image of a contact between claystone and sandstone. Hematite (bright) and rutile either fill cracks in the upper part of the sandstone, or the oxides and clays have squeezed into between quartz grains, forming flame-like structures, both being consistent with a sedimentological control over the oxide distribution, i.e., their detrital origin. Petäjäskoski. C) BSE image of a 1-mmthick, massive siltstone lamina between graded claystone laminae. Hematite (bright) is coarser and less abundant in the siltstone layer. The black grains are quartz. Petäjäskoski. D) BSE image showing euhedral shapes of hematite grains. Irregular-shaped apatite (grey) is abundant in this phlogopitic mudstone. Rumatmaat.

graded layers, hematite is concentrated to their upper parts (Fig. 5B), whereas in the thinner laminae, it is evenly distributed. Thin hematite stripes may mark the layer boundaries locally both in the mudstones and albite schists.

In the red sandstones, the coarser hematite grains are concentrated in the lower or upper boundaries of the layers and are more fine-grained than the associated quartz grains. Locally, hematite and rutile have been squeezed from the mudstones into spaces between quartz clasts in adjacent sandstones (Fig. 8B).

The $\mathrm{TiO}_{2}$ contents of hematite are typically high (averaging 1.9 wt.\%). Differences in the $\mathrm{TiO}_{2}$ contents between samples are observed, but the variation between individual grains within a sample may be large. The $\mathrm{Cr}_{2} \mathrm{O}_{3}$ and $\mathrm{V}_{2} \mathrm{O}_{3}$ contents range typically from below the detection limit to about 1 and 0.45 wt.\%, respectively. Variation within a sample is typically large. A few grains yielded $\mathrm{Cr}_{2} \mathrm{O}_{3}$ 
contents between 1.2 and 6.7 wt.\%. As expected, $\mathrm{TiO}_{2}$ has a negative correlation with $\mathrm{Fe}_{2} \mathrm{O}_{3}$ and a good positive correlation with $\mathrm{V}_{2} \mathrm{O}_{3}$ but also with $\mathrm{BaO}$. The highest $\mathrm{BaO}(2340 \mathrm{ppm})$ and $\mathrm{TiO}_{2}(9.8$ wt.\%) contents coincide. Roughly, a group of hematites high in $\mathrm{Cr}_{2} \mathrm{O}_{3}$ and low in $\mathrm{TiO}_{2}-\mathrm{V}_{2} \mathrm{O}_{3}-$ $\mathrm{BaO}$ and another group low in $\mathrm{Cr}_{2} \mathrm{O}_{3}$ and high in $\mathrm{TiO}_{2}-\mathrm{V}_{2} \mathrm{O}_{3}-\mathrm{BaO}$ can be discerned. Concentrations of $\mathrm{P}_{2} \mathrm{O}_{5}$ up to 0.12 wt. $\%$ were measured.

Rutile is commonly associated with hematite though is substantially lesser in abundance and typically finer-grained. It has similar $\mathrm{Cr}_{2} \mathrm{O}_{3}$ contents and slightly higher $\mathrm{V}_{2} \mathrm{O}_{3}$ contents than hematites $\left(\mathrm{V}_{2} \mathrm{O}_{3}\right.$ avg 0.79 wt.\%).

\subsection{Tourmaline}

Disseminated, fine-grained $(<100 \mu \mathrm{m})$ tourmaline is common in the mudstones and is observed in the albite schists, too. Millimeter-thick tourmaline laminae, consisting of 70 to 90 modal-\% of tourmaline, are rather common as well (Figs. 9C, D). The grains are typically euhedral and zoned. Coarser, poikiloblastic tourmaline grains are observed locally. In the siltstone and sandstone layers, tourmaline is less abundant.

Tourmaline has an ideal formula of $\left(\mathrm{XY}_{3} \mathrm{Z}_{6}\right.$ $\left.\mathrm{BO}_{3}\right)_{3} \mathrm{Si}_{6} \mathrm{O}_{18}(\mathrm{OH}, \mathrm{F})_{4}$ with the $\mathrm{X}$ site filled with $\mathrm{Na}$, $\mathrm{Ca}, \mathrm{K}$ or vacancy, $\mathrm{Y}$ site with $\mathrm{Mg}, \mathrm{Fe}, \mathrm{Mn}$ and $\mathrm{Al}$,
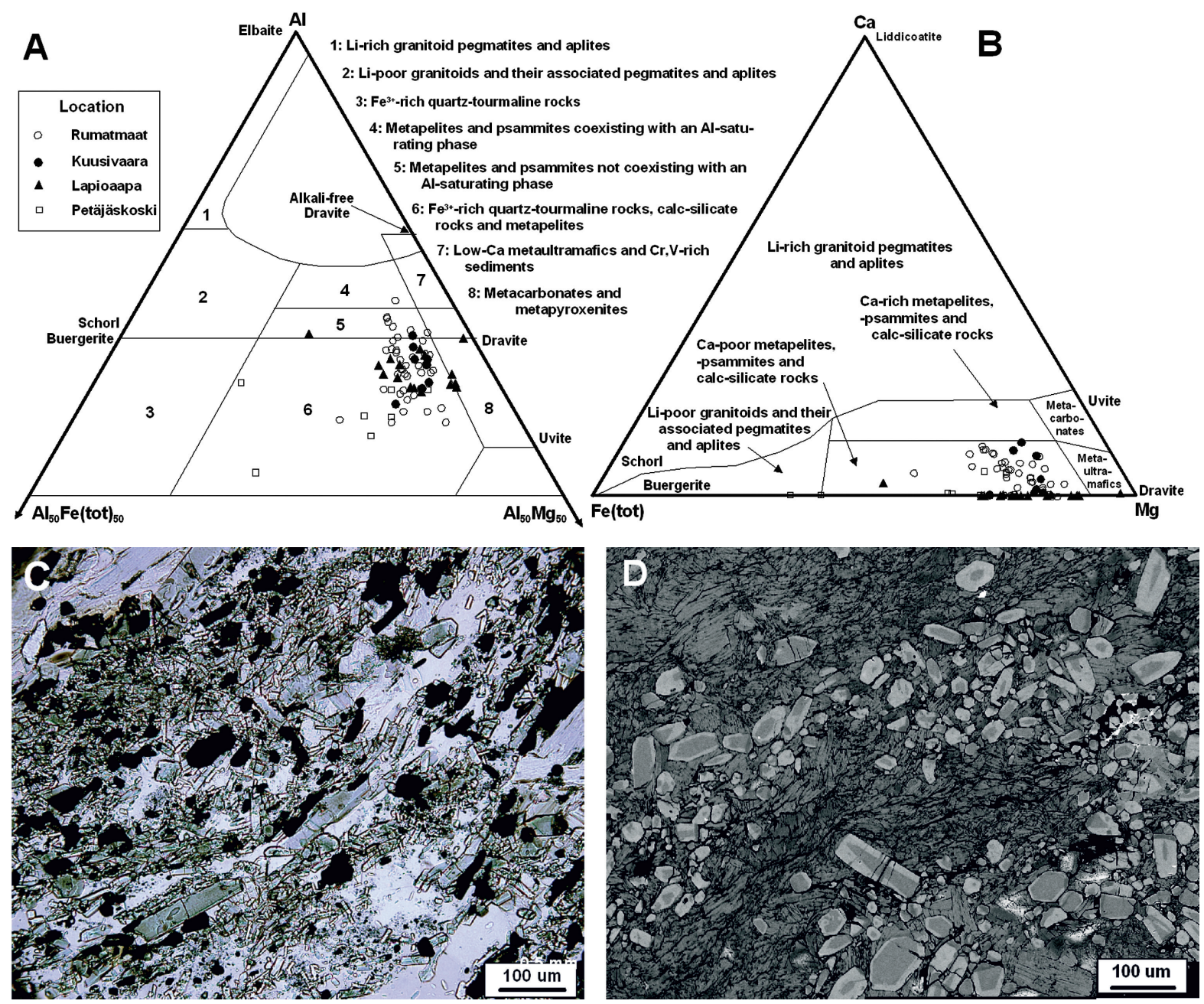

Fig. 9. A) Al-Fe ${ }_{\text {tot }}-\mathrm{Mg}$ and B) Ca-Fe ${ }_{\text {tot }}-\mathrm{Mg}$ diagrams (in molar units) for tourmaline from the Petäjäskoski Formation. Fields after Henry and Guidotti (1985). C) Photomicrograph of a tourmaline-rich layer in mudstone. Opaque grains are hematite, and tourmaline is green. Rumatmaat. D) BSE image of a tourmaline-rich layer in albite schist. Note zoned tourmaline. Lapioaapa. 
and $\mathrm{Z}$ site with $\mathrm{Al}, \mathrm{Fe}, \mathrm{Cr}$ and $\mathrm{V}$ (Henry et al., 2011). Calculated tourmaline formulae and $\mathrm{H}_{2} \mathrm{O}$ and $\mathrm{B}_{2} \mathrm{O}_{3}$ contents are based on the assumption that $\mathrm{B}$ and $\mathrm{H}_{2} \mathrm{O}$ are present in stoichiometric quantities (Table $1)$. If the $Z$ sites shows a deficiency, as is the case nearly always, it is filled with $\mathrm{Fe}^{3+}$ (e.g., Henry \& Guidotti, 1985).

Most tourmalines in the PFm rocks are dravitic in composition with $\mathrm{Na} /(\mathrm{Na}+\mathrm{Ca})$ and $\mathrm{Mg} /(\mathrm{Mg}+\mathrm{Fe})$ values falling in the ranges of $0.53-1.0$ and $0.7-$ 0.9 , respectively. The composition of the host rock is reflected in the tourmaline chemistry: tourmalines in the mudstones are richer in $\mathrm{CaO}$ and poorer in $\mathrm{Na}_{2} \mathrm{O}[\mathrm{Na} /(\mathrm{Na}+\mathrm{Ca})$ avg 0.75$]$ than those in the albite schists $[\mathrm{Na} /(\mathrm{Na}+\mathrm{Ca})$ avg. 0.98$]$. The cores are commonly richer in $\mathrm{Ca}$ and $\mathrm{Mg}$ and poorer in $\mathrm{Fe}$ and $\mathrm{Al}$ than the rims, causing the brighter color of the latter in BSE images (Fig. 9D).

In the "environmental" $\mathrm{Al}-\mathrm{Fe}$ (tot)-Mg plot of Henry and Guidotti (1985) shown in Fig. 9A, most tourmalines cluster in the field of ' $\mathrm{Fe}^{3+}$-rich quartztourmaline rocks, calc-silicate rocks, and metapelites'. Some tourmalines, mainly those from the Rumatmaat area, plot in the field of 'metapelites and metapsammites not coexisting with an Alsaturating phase'. In the $\mathrm{Ca}-\mathrm{Fe}$ (tot)-Mg plot (Fig. 9B), all tourmalines plot in the field of 'Ca-poor metapelites, metaspammites, and quartz-tourmaline rocks'. Tourmalines from the albite schists and plagioclase-deficient mica schists are $\mathrm{Ca}$-free and lie on the $\mathrm{Fe}_{\text {tor }}-\mathrm{Mg}$ tie line. In general, tourmalines of dravitic composition are typical of metaevaporitic sequences (cf. Warren, 1999; Henry et al., 2008).

\subsection{Apatite, monazite and zircon}

Apatite, monazite and zircon are common accessory minerals within the PFm. In the claystones, siltstones and sandstones, apatite occurs as rounded to subhedral to highly irregular grains up to 100 $\mu \mathrm{m}$ in size, in some places intergrown with hematite. The $\mathrm{F}, \mathrm{Cl}$ and $\mathrm{H}_{2} \mathrm{O}$ contents of apatite average 2.2, $0.3,0.4$ wt. $\%$, respectively, which classify the mineral mainly as fluor-apatite. The monazite and zircon grains are usually less than $100 \mu \mathrm{m}$ in diameter. Zircon usually occurs as rounded detrital grains, whereas monazite grains are more irregular in shape. Both are observed in the mudstones and siltstones.

\subsection{Anhydrite}

In one sample from Petäjäskoski, tiny anhydrite crystals $10-20 \mathrm{~mm}$ in size were identified by electron microprobe as inclusions in quartz (Fig. 10) in a quartz-filled nodule (cf. Fig. 4F). The same nodule also contains thin baryte veinlets.

\section{Geochemistry of Petäjäskoski Formation}

Table 3 presents chemical compositions of siliciclastic rocks and one dolomite sample from the Petäjäskoski Formation, and Fig. 11 shows a more extensive collection of analyses from the formation, plotted on several variation diagrams. To highlight the unusual geochemical characteristics of the PFm metasediments, these diagrams include compositions of other sedimentary rocks from Finnish Karelian supracrustal belts. The reference data $(\mathrm{n}=$ 530) for the latter were collected from the rock geochemical database of Finland (RGDB, Rasilainen et al., 2008). A comparison is also made with an average Proterozoic cratonic shale (Condie, 1993) and various igneous rocks including the Jouttiaapa basalts overlying the PFm and mafic to felsic tuffites and tuffs from the Peräpohja Belt (RGDB data supplemented by data from Perttunen \& Hanski, 2003 and Hanski et al., 2005), typical mafic and felsic plutonic rocks (Wedepohl, 1969) and some ultrapotassic melagranites and melasyenites (Kotková et al., 2010).

The sericitic mudstones have high $\mathrm{Al}_{2} \mathrm{O}_{3}(-19-$ 23 wt. \%) and $\mathrm{K}_{2} \mathrm{O}(-7-9$ wt.\%) contents and moderate $\mathrm{MgO}$ contents $(-4-5$ wt.\%) compared to the phlogopitic mudstones, which are high in $\mathrm{MgO}\left(-7-11\right.$ wt.\%) and lower in $\mathrm{Al}_{2} \mathrm{O}_{3}(-15 \mathrm{wt} . \%)$ and $\mathrm{K}_{2} \mathrm{O}(-3.5-5.5$ wt.\%) (Table 3, Fig. 11). Reflecting the relative abundances of phlogopite and sericite in the mudstones, $\mathrm{MgO}$ and $\mathrm{K}_{2} \mathrm{O}$ show a strong negative correlation $(\mathrm{r}-0.78)$ and $\mathrm{Al}_{2} \mathrm{O}_{3}$ and $\mathrm{MgO}$ depict a curvilinear trend (Fig. 11C): $\mathrm{Al}_{2} \mathrm{O}_{3}$ 

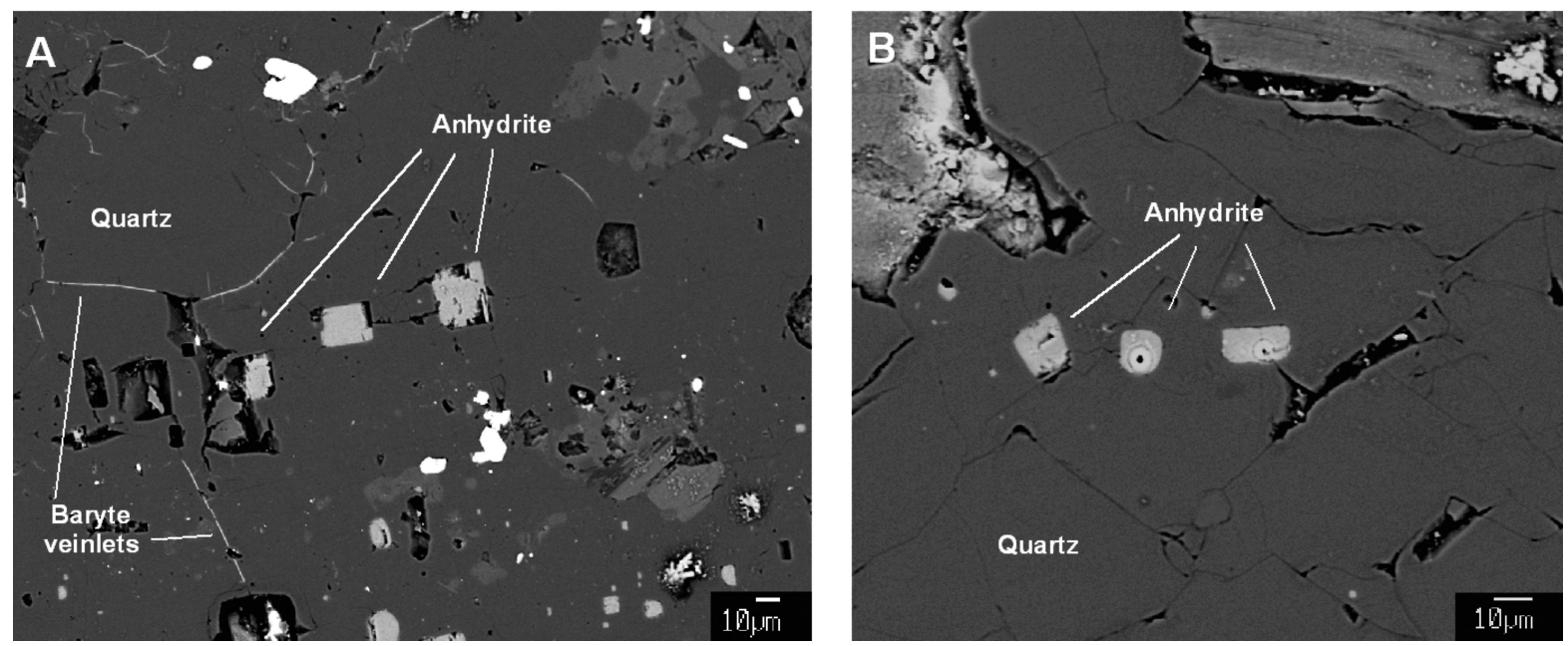

Fig. 10. BSE images of anhydrite inclusions and baryte veinlets in quartz of a quartz-filled nodule in mudstone, Petäjäskoski.

and $\mathrm{MgO}$ display strong negative correlation in sericitic mudstones, whereas in the phlogopitic mudstones, the $\mathrm{MgO}$ contents vary widely in the narrow $\mathrm{Al}_{2} \mathrm{O}_{3}$ range.

The $\mathrm{FeO}_{\text {tot }}$ and $\mathrm{SiO}_{2}$ contents are similar in the two end-member mudstone types, and range from -9 to $15 \mathrm{wt} . \%$ and from 47 to $52 \mathrm{wt} . \%$, respectively. Their negative correlation ( $r-0.73)$ originates from the enrichment of hematite in the claystones. There is no correlation between $\mathrm{CaO}$ and $\mathrm{Na}_{2} \mathrm{O}$. Their contents range from below the detection limit to maximum values of 2.5 and $3.4 \mathrm{wt}$.\%, respectively, but are commonly at the lower end of the spectrum. On the other hand, $\mathrm{Na}_{2} \mathrm{O}$ and $\mathrm{MgO}$ have a good positive correlation ( $\mathrm{r}$ 0.69), especially among the Petäjäskoski samples (r 0.84). This is chiefly explained by the coexistence of phlogopite and miscellaneous $\mathrm{Na}$-rich phyllosilicates (dominantly phyllosilicates of Group 4). The highest $\mathrm{CaO}$ contents are explained by the presence of carbonates and plagioclase. The $\mathrm{TiO}_{2}$ content is relatively high due to abundant rutile and hematite. As is seen in Fig. 11, the PFm mudstones differ from other Karelian metasedimentary rocks mainly due to their high $\mathrm{MgO}, \mathrm{FeO}$ and $\mathrm{K}_{2} \mathrm{O}$ contents.

Because only two albite-rich samples were analyzed, major element covaritions in the albitic succession cannot be assessed. The analyzed albiterich metasediments are high in sodium with the maximum of 10 wt. $\% \mathrm{Na}_{2} \mathrm{O}$ translating to c. $85 \%$ of modal albite. Instead, the Si, Fe and Ti contents are similar to those of the mudstones in general, while the $\mathrm{Al}_{2} \mathrm{O}_{3}$ content is similar to that in the phlogopitic mudstones.

With some exceptions, the trace element contents are markedly similar in the mudstones and albite schists. The concentrations of the transition elements Sc, Mn and $\mathrm{Ni}$ are lower in the albite schists. The mudstones have clearly higher $\mathrm{Ba}(310-$ 2520 ppm vs. $26-54 \mathrm{ppm})$ and $\mathrm{Rb}$ (107-223 vs. 8-16 ppm) contents reflecting the high abundance of K-micas, particularly sericite. Compatible with the small amount or absence of $\mathrm{Ca}$-bearing plagioclase, $\mathrm{Sr}$ contents in the mudstones are low (8-36 ppm) and below the detection limit in the albite schists.

Primitive mantle-normalized multielement and chondrite-normalized REE patterns for the PFm siliciclastics are presented in Fig. 12. The mudstones and albite schists show similar REE patterns with sloping LREE and flat HREE. Negative Eu anomalies are distinct $\left(\mathrm{Eu} / \mathrm{Eu}^{*} 0.63-0.75\right)$, whereas no $\mathrm{Ce}$ anomalies are observed. The spidergram of Fig. 12B displays clear negative anomalies at $\mathrm{Sr}, \mathrm{Nb}$ and $\mathrm{Ta}$, and a strong positive $\mathrm{K}$ anomaly for the mudstones but a negative one for the albite schist sample, which expectedly also displays a negative $\mathrm{Ba}$ anomaly. The $\mathrm{Sr}, \mathrm{Nb}$ and $\mathrm{Ta}$ contents are substantially lower compared to an average Proterozoic cratonic shale, which in turn has a lower 

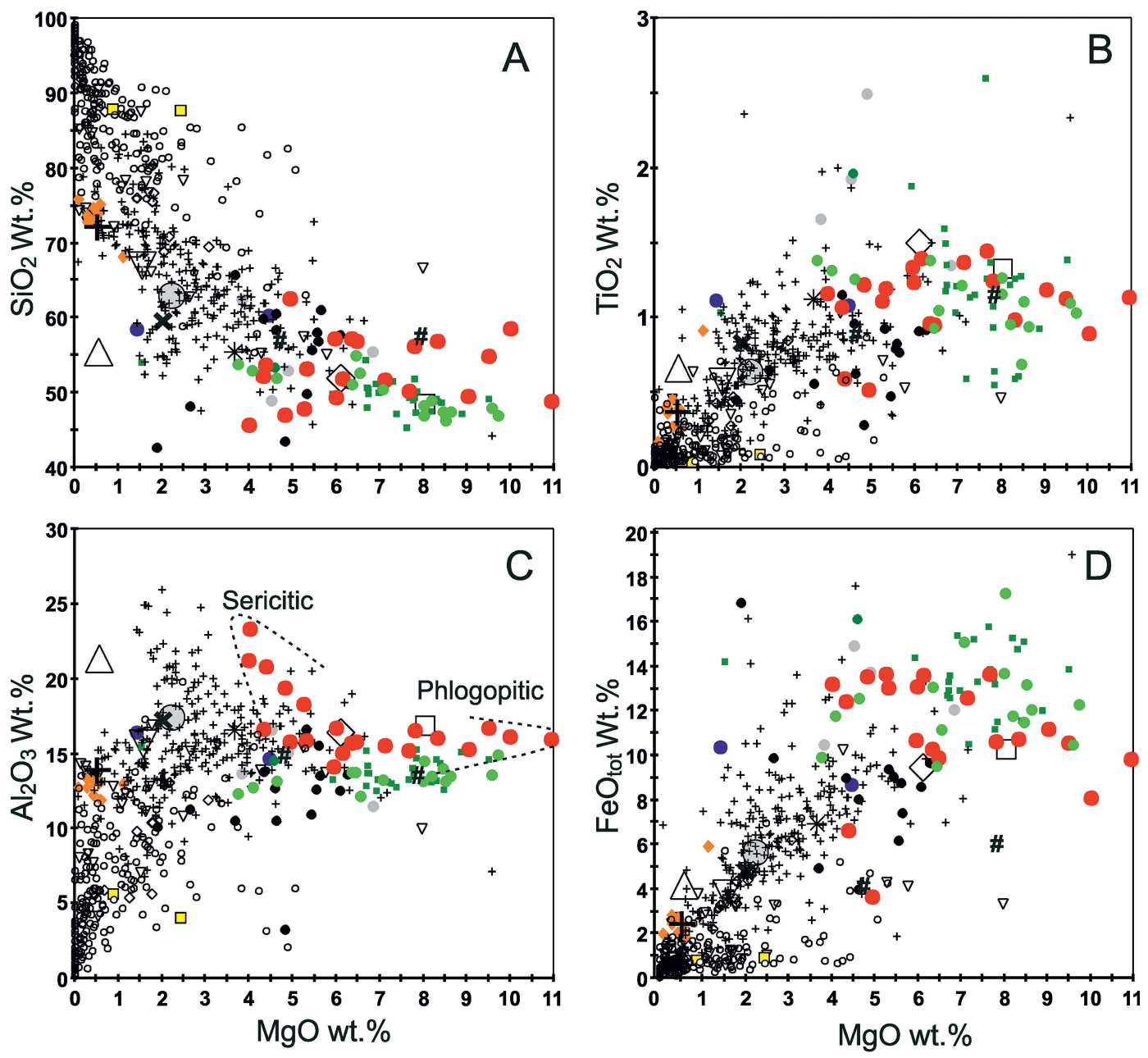

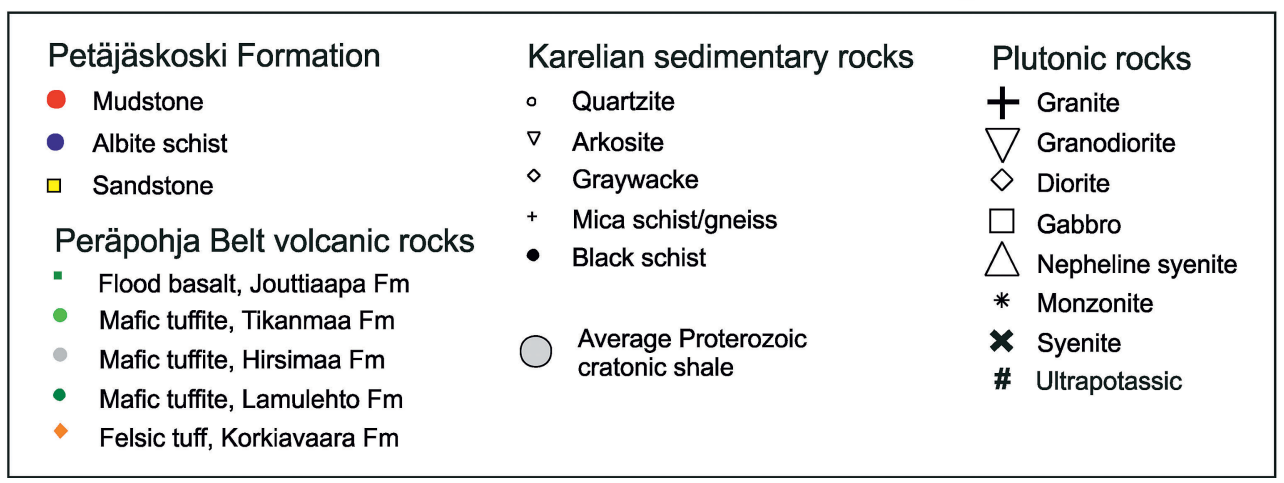

Fig. 11. Bivariate plots for the Petäjäskoski Formation siliciclastics and reference data (for data sources, see text).

Ti content compared to the PFm mudstones and albite schists.

The strong positive correlation observed between $\mathrm{LREE}$ and $\mathrm{Al}_{2} \mathrm{O}_{3}$ in the mudstones implies a clay/mica control over LREE. A similar correlation is observed in the albite schists. The positive correlations of HREE, Ta, Y, and Nb with P, Th, and $\mathrm{Zr}$ suggest that their distribution is controlled by zircon and monazite, while the positive correlations between Fe, Ti, Cr, V and Sc indicate that their distribution is controlled chiefly by oxides. The REE concentrations in the sandstones are 

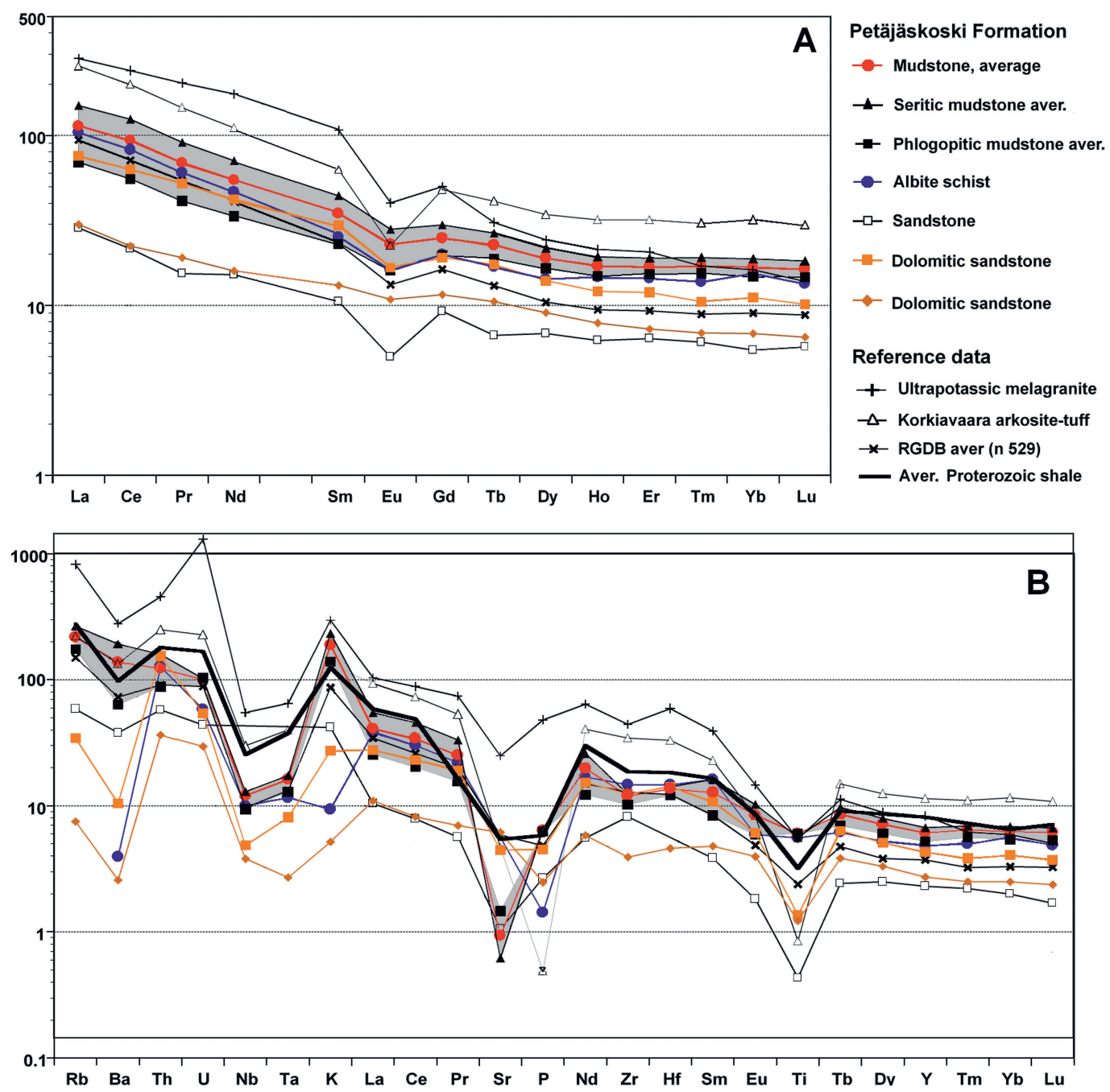

Fig. 12. A) chondrite-normalized REE and B) primitive mantle-normalized multielement patterns for the Petäjäskoski Formation siliciclastics and selected reference data. The gray zone marks the compositional range of average sericitic to phlogopitic PFm mudstone. Normalizing values taken from McDonough and Sun (1995).

lower compared to the mudstones due to the dilution effect of quartz and carbonates. Otherwise the patterns are similar, though the dolomite-richest sandstone displays no Eu anomaly. The REE and multielement patterns of the PFm sandstones are similar to the mudstones except for $\mathrm{Sr}$ which is, expectedly, enriched in the dolomitic sandstones.

Table 3 lists an average composition of 12 samples from the Kuusivaara sill intruding the Petäjäskoski Formation. Also shown is an average composition of four diabase samples from Kätkävaara, based on the data published by Perttunen and Hanski (2003). Compared to the differentiated sills of the $2.22 \mathrm{Ga}$ gabbro-wehrlite association (GWA), common in the lower parts of the Palokivalo Formation, the mafic sills intruding the PFm are geochemically distinct. This is evident, for example, in the $\mathrm{Al}_{2} \mathrm{O}_{3} / \mathrm{TiO}_{2}$ versus $\mathrm{MgO}$ plot of Fig. 13A, where the PFm sills form a narrower $\mathrm{MgO}$ but higher and wider $\mathrm{Al}_{2} \mathrm{O}_{3} / \mathrm{TiO}_{2}$ range compared to the GWA sills. The PFm sills also display distinctly flatter chondrite-normalized REE patterns than the GWA sills, which are strongly enriched in LREE compared to HREE (Fig. 13B). On the other hand, Figs. 13A-B show that the mafic sills from Vammavaara and Kätkävaara, which were studied 
by Perttunen and Hanski (2003), are chemically similar to those intruding the PFm.

\section{Geochronology}

The small amount of zircon obtained from the Kuusivaara mafic sill A2087 consists of turbid, brownish, subhedral, magmatic grains. In BSE images, altered domains are common. The U-Pb isotope data are listed in Table 4 and shown graphically in Fig. 14. Twenty-one analyses were made on A2087 and 19 of these give a concordia age of 2140 $\pm 11 \mathrm{Ma}$ (Fig. 14A). One data point has been rejected due to a relatively high amount of common lead (12a) and one analysis on an altered domain gives clearly a younger age (13a).

In the Petäjäskoski quartzite sample (A2089), zircon grains are moderately rounded. Forty-four analyses on 43 zircon crystals were made (Fig. 14B). All measured ages are Archean falling in the range of c. 2650-3100 Ma with the exception of three grains which record ages between 3330-3470 Ma. Despite the $\mathrm{MgO}$-rich nature of the Petäjäskoski Formation, zircon grains derived from older Paleoproterozoic mafic igneous rocks seem to be absent in sample A2089.

\section{Discussion}

\subsection{Time constraints on sedimentation}

On the basis of major and trace element geohemistry, Perttunen and Hanski (2003) postulated that mafic sills intruding the Palokivalo Formation in the Vammavaara area belong to a younger age group than the GWA sills. Geochemically, the former sills match with those intruding the PFm (Fig. 13A). The age of $2140 \pm 11$ Ma obtained for the Kuusivaara sill in this work is representative of the time of intrusion of the younger age group and also provides a minimum age for the sedimentation of the Petäjäskoski Formation. A differentiated mafic sill intruding the Palokivalo Formation at Kaakamovaara has been dated at $2117 \pm 6 \mathrm{Ma}(\mathrm{U}-\mathrm{Pb}$ zircon data), and a nondifferentiated sill c. $100 \mathrm{~m}$ higher in the stratigraphy yielded an age of $2129 \pm 2 \mathrm{Ma}$ (Pb-Pb titanite data) (Perttunen \& Vaasjoki, 2001). However, no whole-rock geochemical data are available for these dated sills. If the sills at Vamma-
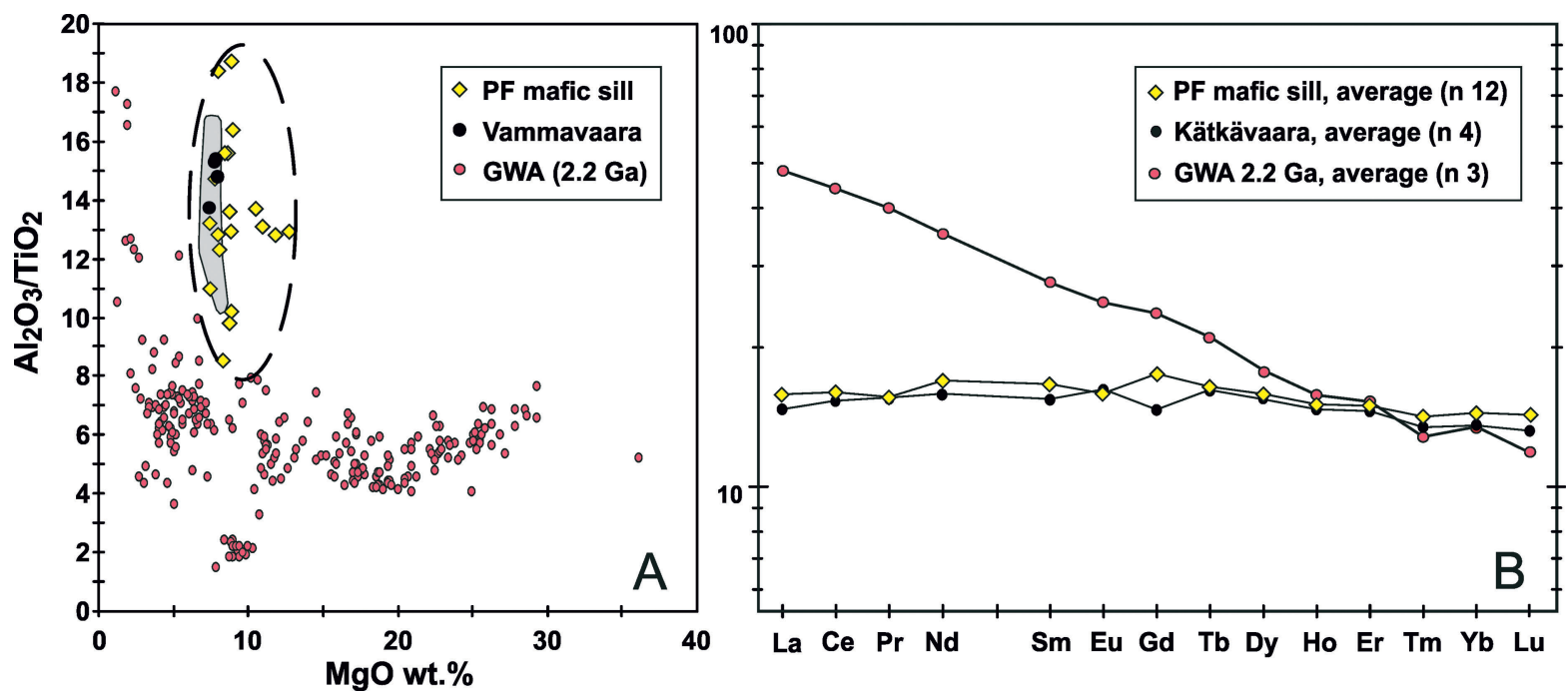

Fig. 13. $\mathrm{Al}_{2} \mathrm{O}_{3} / \mathrm{TiO}_{2}$ vs. MgO plot (A) and chondrite-normalized REE patterns (B) for analyses from massive mafic sills (PFm) intruding the Petäjäskoski Formation (compositions outlined by a dashed line in A) and and similar sills intruding quartzites in the Vammavaara and Kätkävaara areas. These are compared with differentiated, 2.22 Ga mafic-ultramafic sills (GWA) from northern and eastern Finland (data from Perttunen and Hanski 2003). Grey field in A in for mafic intrusions with non-fractionated chondrite-normalized REE patterns from the Peräpohja Belt after Perttunen and Hanski (2003). Normalizing values taken from McDonough and Sun (1995). 

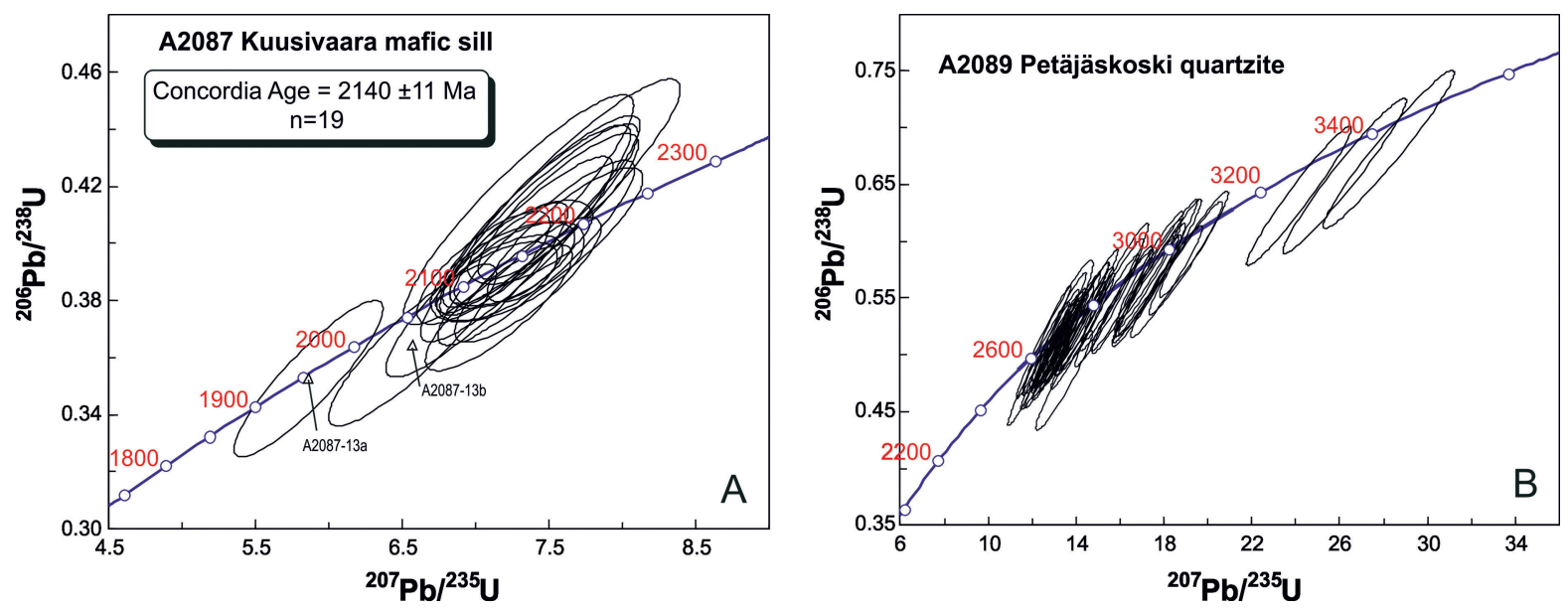

Fig. 14. A) Concordia diagrams of U-Pb data (A) for magmatic zircons (A) from a mafic sill (sample A2187), Kuusivaara, and (B) for detrital zircons from a quartzite (sample A2089), Petäjäskoski. Ellipses represent $2 \sigma$ errors.

vaara and Kaakamovaara, and, by analogy, those intruding the PFm, belong to the same age group, they would constrain the maximum depositional age of the PFm to c. 2.1 Ga. Tuffites of the Hirsimaa Formation in the upper part of the Kivalo Group dated at $2106 \pm 8 \mathrm{Ma}(\mathrm{U}-\mathrm{Pb}$, Karhu et al., 2007) give similar constraints.

The Palokivalo Formation quartzites are cut by strongly differentiated, $2.22 \mathrm{Ga}$ mafic-ultramafic sills (cf. Hanski et al., 2010), but there is no evidence showing that these sills reach the stratigraphic level of the Petäjäskoski Formation. This together with the c. $2.14 \mathrm{Ga}$ age of the Kuusivaara sill allows us to bracket the depositional age of the Petäjäskoski Formation between c. 2.22 and $2.14 \mathrm{Ga}$.

The positive $\delta^{13} \mathrm{C}$ values obtained from the PFm dolostones are typical of sedimentary carbonate rocks deposited during the Paleoproterozoic marine carbon isotope excursion (Karhu, 1993). Most of the carbonate rocks in the Peräpohja Belt, including those recording a positive $\delta^{13} \mathrm{C}$ anomaly, occur higher in the stratigraphy, largely in the Rantamaa Formation postdating the Jouttiaapa Formation (Karhu, 1993). The high- $\delta^{13} \mathrm{C}$ dolomites reported from the upper part of the Petäjäskoski Formation demonstrate that the Lomagundi-Jatuli event started in this area before the eruption of the flood basalts of the Jouttiaapa Formation, with its commencement dating back to earlier than c. 2.14 Ga but potentially later than c. $2.22 \mathrm{Ga}$.

\subsection{Depositional environment}

The presence of ripple marks in the sandstones, stromatolites in the dolostones, and desiccation cracks in the mudstones (Fig. 4D) with the latter attesting to intermittent subaerial exposure, show that the Petäjäskoski Formation sediments were deposited in a shallow-water to subaerial environment. The platform, which was extensive based on the areal distribution of the PFm, eventually emerged when the subaerial lavas of the Jouttiaapa Formation extruded on the PFm.

The flaser, wavy and lenticular bedding structures observed in the siliciclastic sequence are characteristic of intertidal zones of tidal flats (Reineck \& Wunderlich, 1960). Flaser bedding, typified by beds where sand/silt ripples are draped by thin clay layers (see Fig. 4C) are typical of sand flats located in seaside deeper-water parts of tidal flats. Clay becomes dominant towards the shoreside and is exemplified by the appearance of wavy and then lenticular bedding. Though these bedding types are not exclusively restricted to tidal environments (Reineck \& Wunderlich, 1960; Bhattacharya, 1997), these "tidal beds" in the PFm, some with a bidirectional cross-stratification indicative of oscillatory flow, and the rhythmically alternating clay-siltstone couplets (Fig. 4A), are in favor of a tidal environment. Considering the intermittent and 


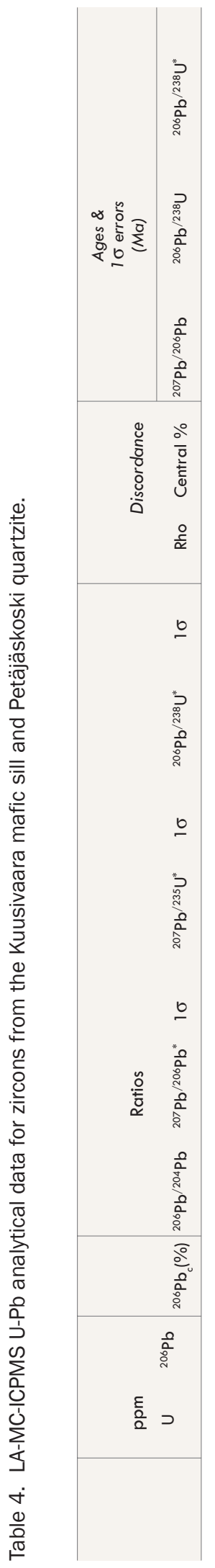

₹ $\forall$ Ұ

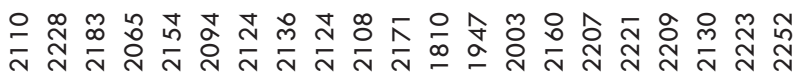

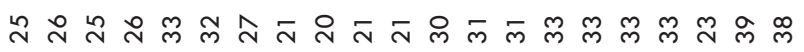

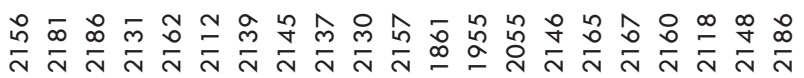

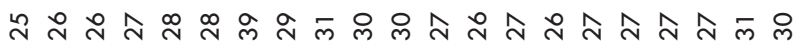

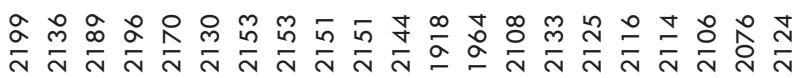

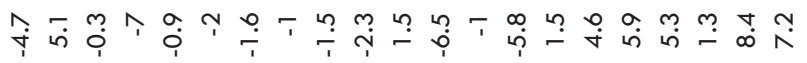

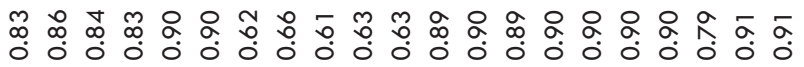
ळ

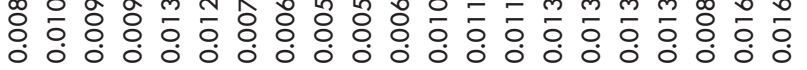

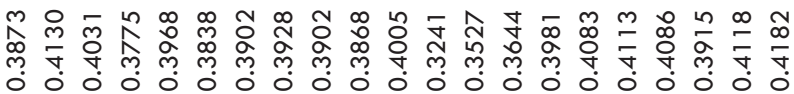

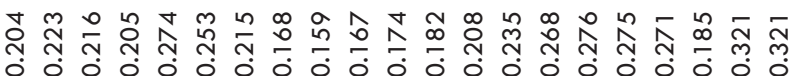

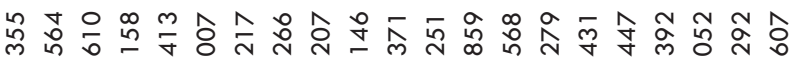

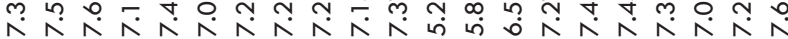

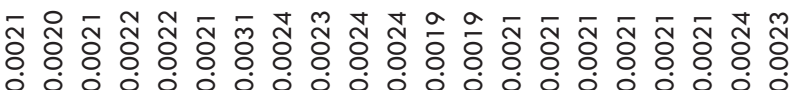

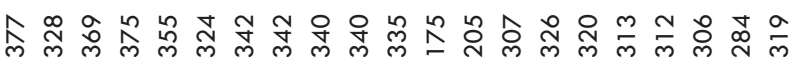

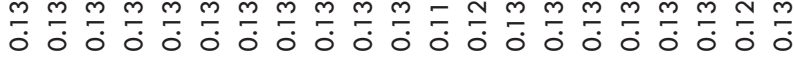

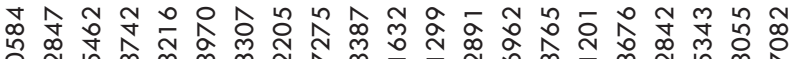

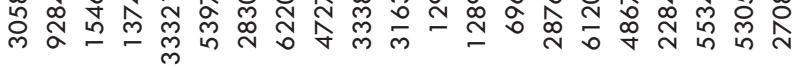

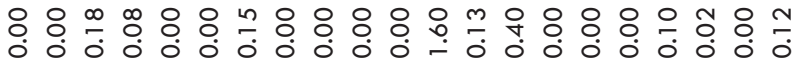

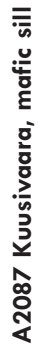

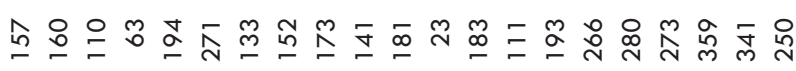

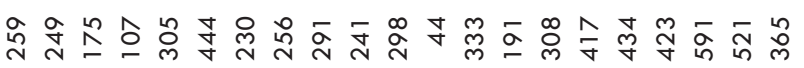

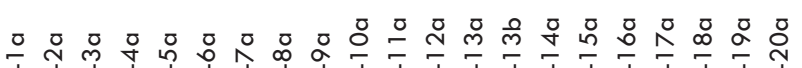

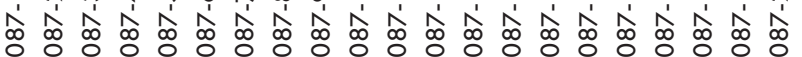

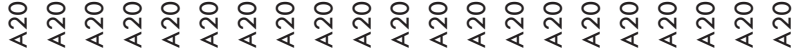

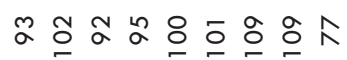

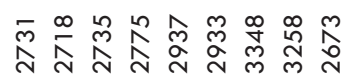

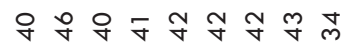

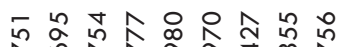

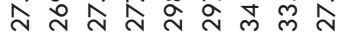

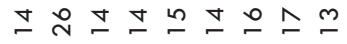

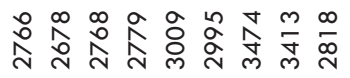

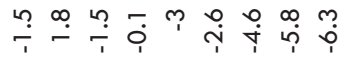

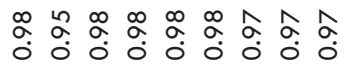

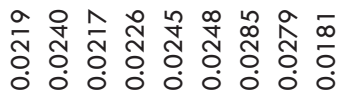

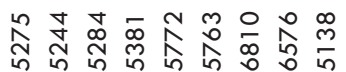

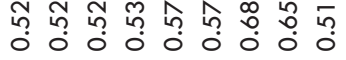

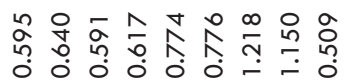

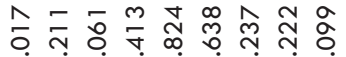

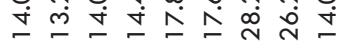

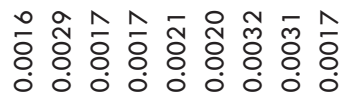

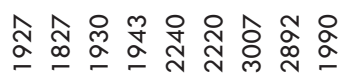
品

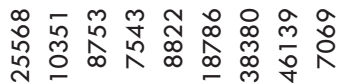

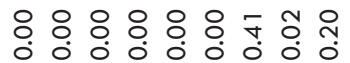

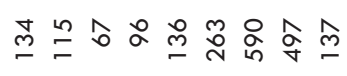

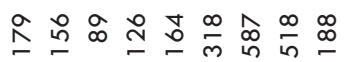

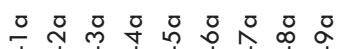

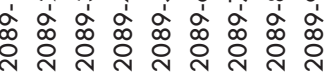




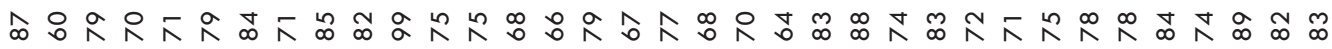

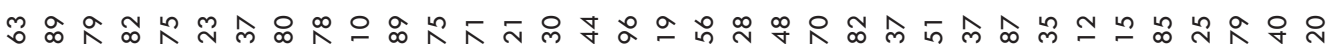

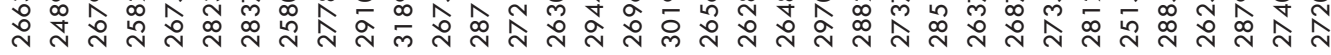

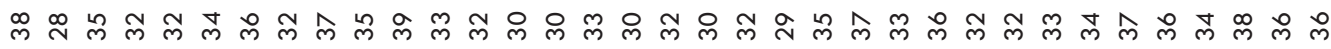

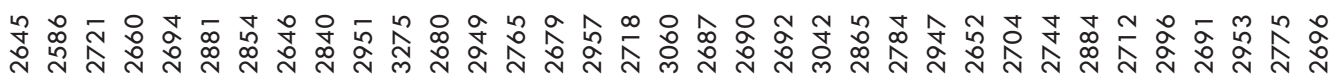

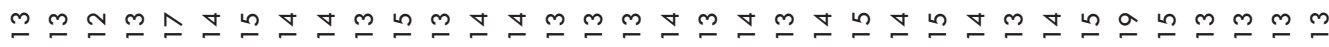

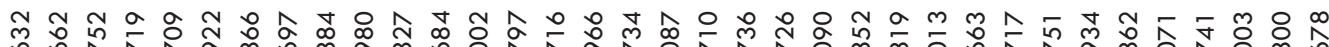

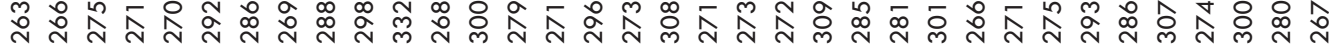

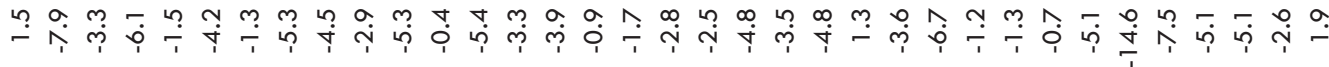

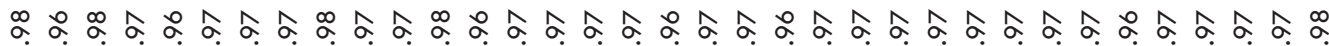

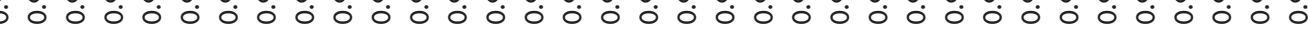

苟息品

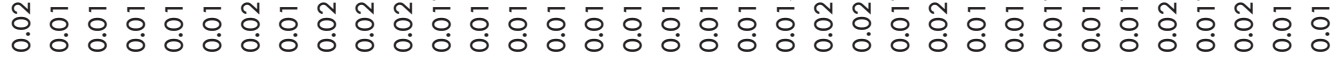

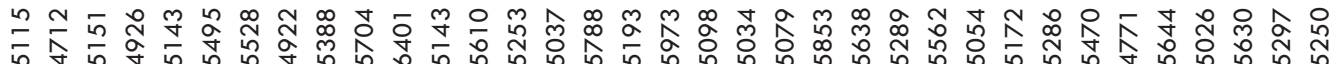

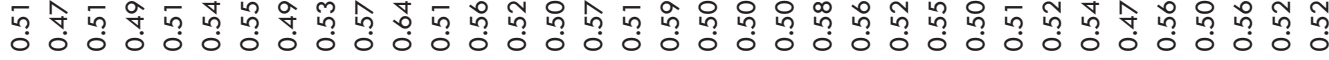

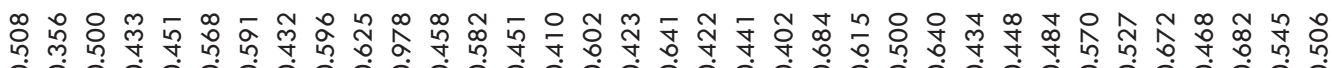

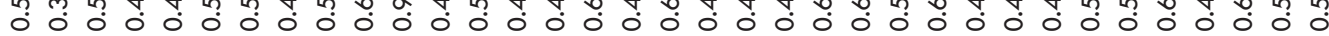

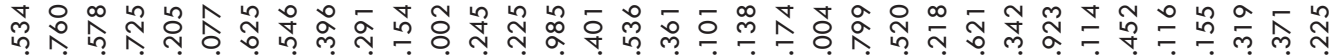

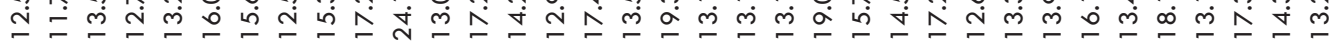

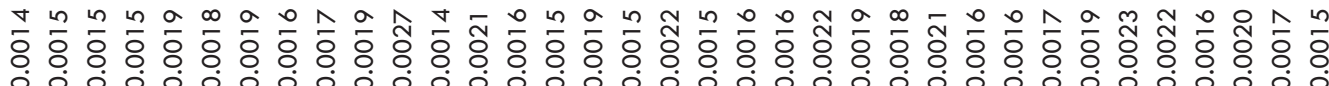

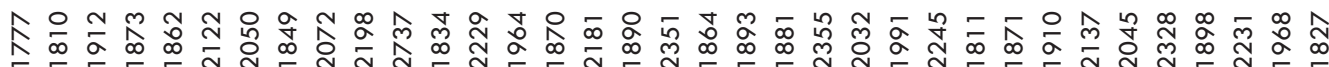
○

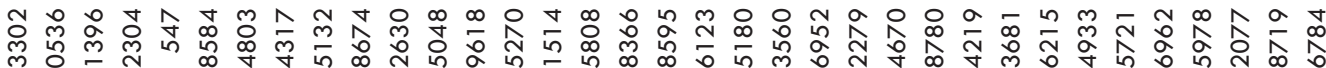

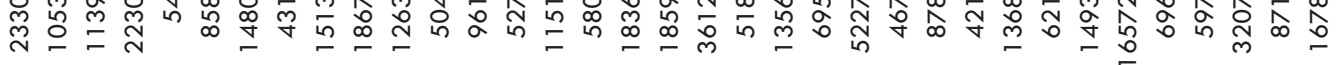

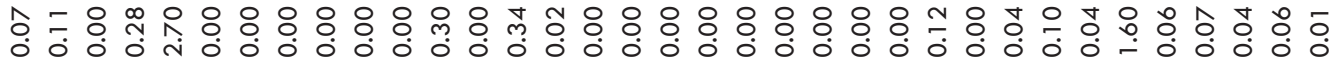
商

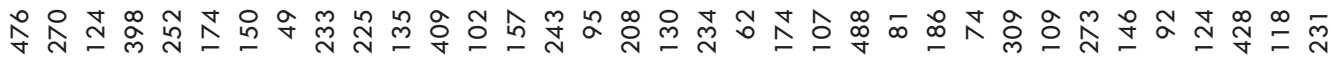

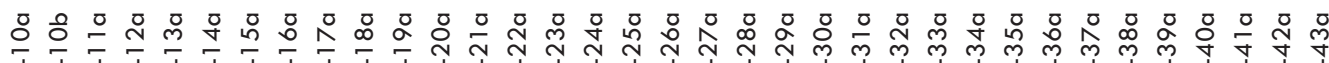

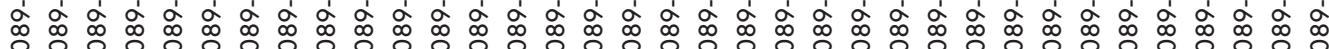

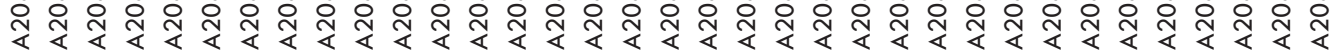


eventual subaerial exposure, wind action may have been significant in driving the sedimentation, too.

\subsection{Genesis of the mudstones and albite schists}

The peculiarity of the PFm mudstones is highlighted by atypical mineral and geochemical compositions including the high $\mathrm{MgO}, \mathrm{FeO}_{\text {tot }}$ and $\mathrm{K}_{2} \mathrm{O}$ contents coupled with the low $\mathrm{CaO}$ and $\mathrm{Na}_{2} \mathrm{O}$ contents. The key mineralogical features are the abundant phlogopite and disseminated hematite with the latter carrying more than $90 \%$ of the iron. The albite schists are, in turn, composed essentially of albite and hematite but have similar geochemical and structural characteristics to those of the mudstones. These features leave room for arguments about the genesis and evolution of the PFm mudstones, albite schists and the whole succession.

Given the strong evidence for an epiclastic sedimentary origin of the mudstones and albite schists (or their protoliths), their chemical compositions can be explained by 1) derivation from a source or sources with similar compositions, and/ or 2) by modification of the original compositions by syn- or post-depositional processes involving addition and/or extraction of some of their components. The potential origin of hematite is crucial in this connection and will be discussed first.

\subsubsection{Origin of hematite and rutile}

Continental red beds, containing pigmentary hematite as an indicator of free oxygen in the Earth's atmosphere, appeared at c. 2.3-2.2 Ga (e.g., Melezhik et al., 2005a), that is, approximately at the same time when the sediments of the Palokivalo Formation were deposited, though the disappearance of the mass-independent fractionation of sulfur isotopes in ancient sedimentary rocks suggests that the "Great Oxygenation Event" (GOE) took place earlier, roughly during the Huronian glaciations somewhere between 2450 and $2320 \mathrm{Ma}$ (Bekker et al., 2004; see also Kump et al., 2012). There is no indication of large-scale reddening in the underlying Palokivalo Formation (V. Perttunen, pers. comm., 2005), but the hematite-bearing PFm rocks might record oxidative conditions.

Hematite in sediments may be of a diverse origin (Friedman \& Sanders, 1978; Turner, 1980). It may be formed, for example, by 1) dehydration of Fe hydroxides present in the sediment, 2) oxidation of ferrous minerals, 3) lateritic weathering, or 4) direct precipitation from water or from pore water during diagenesis. It may also be derived from older red beds or lateritic weathering profiles through their reworking. As the hematite in the PFm schists does not impart a red color and its amount far exceeds that present in typical red beds, the rocks cannot be designated as red beds 'sensu stricto'. However, if the hematite in the PFm schists is detrital in origin, it would suggest derivation from an oxidized source, hence, indirectly indicating oxidizing atmospheric conditions at the time of their deposition. The coloration in the reddish PFm sandstones (Fig. 4C), where crystalline hematite is not present in substantial amounts, is in turn caused by reddishbrownish Fe-oxides/-hydroxides overprinting miscellaneous phyllosilicates of a possible primary detrital origin. This could indicate that the reddening is caused by the syn-depositional to diagenetic red bed-forming processes mentioned above as pigment is not observed over metamorphic micas except in some near-surface samples.

The hypothesis of hydrothermal origin of hematite in the PFm mudstones and albite schists seems improbable. Hydrothermal introduction of iron for hematite would likely not have resulted in grading and a distinct selective distribution of hematite but instead volume changes and subsequent disruption of sedimentary structures. Also, only a minor amount of hematite is present in the sandstones where hydrothermal flow would probably have been focused due to their higher permeability. Such an origin is not supported either by the fact that mudstones or albite schists without hematite have not been encountered.

As noted earlier, hematite in red beds occurs merely as a pigment and hence the diagenetic 'reddening processes' cannot explain the abundant hematite either. Diagenetic hematite concretions 
enriched in $\mathrm{Al}, \mathrm{Ti}, \mathrm{Cr}, \mathrm{V}$ and $\mathrm{Ni}$ are known to precipitate in acid $(\mathrm{pH}<4)$ or otherwise chemically extreme sedimentary environments (Bowen et al., 2008). However, these concretions are substantially coarser in grain size $(\sim 0.1 \mathrm{~mm})$.

Local occurrences of hematite aggregates and the euhedral shape of the grains (Fig. 8D) would suggest that hematite was (re-)crystallized in situ in the rocks. This is supported by the similar trace element contents of hematite grains in a given sample coupled with their systematic compositional variations between samples. However, the distribution of hematite and rutile could be better explained with their (or their precursor's, see below) original detrital origin. A mechanical control over their distribution is indicated firstly by their grading (variations in the grain size and amount) and concentration at layer boundaries (see Figs. 4A, 4B, $6 \mathrm{~F}, 8)$. Figure $8 \mathrm{~B}$ shows an example of a boulder sample further corroborating the potential detrital origin: 1) either the oxides fill cracks opened in the sandstone underlying the mudstone, or 2) the oxides have been squeezed into the space between quartz grains by loading of the sand by the overlying mudstone. As banded iron formations (BIF) are typically relatively poor in elements such as $\mathrm{Al}, \mathrm{Ti}$, V, P, Sc and Cr (e.g., Mücke et al., 1996; Spier et al., 2007), the composition of analysed hematite excludes an direct erosional derivation from such deposits.

It is possible that hematite formed by in situ oxidation and recrystallization of other detrital minerals with similar densities, for example, magnetite, ilmenite (producing hematite and rutile) or pyrite. However, no magnetite or sulfides have been observed in these rocks. Relative abundances of hematite and rutile also exclude ilmenite as the only source of hematite, and given the likely oxidizing conditions, occurrence of detrital pyrite in the sediments seems unrealistic, too. Detrital pyrite is common only in sediments deposited prior to the oxygenation of the atmosphere (e.g., Bekker et al., 2005). Thus, it seems likely that the euhedral shape and the systematic compositional variations resulted from recrystallization of hematite within the diagenetic-metamorphic realm. In summary, of the possible origins of hematite, a detrital one seems most feasible.

\subsubsection{Relationship between the mudstones and albite schists}

Mudstones and albite schists have not been observed to occur interbedded. Although the former locally contain albite and the latter phlogopite, no clear transitional relationship between the two has been observed. However, many lines of evidence, including their stratigraphic position immediately below the basaltic Jouttiaapa Formation, their similar hematite dissemination and structural and textural features (Fig. 5), together with immobile trace element compositions (Fig. 11B) suggest that they are inextricably intertwined. If they had a completely different primary origin, they would likely display different trace element characteristics.

In alteration processes involving fluids, the number of phases in an altered rock tends to be minimized as the system approaches equilibrium between the rock and fluid (e.g., Reed, 1997). Therefore, the albite schists containing practically only albite and hematite, can be thought to be alteration products of mudstones. In that case, aluminous phases and quartz were altered to albite, whereas hematite, as a non-aluminous phase, was not reactive. The chemical compositions of the albite schists and mudstones (Table 3) suggest that the alteration involved significant introduction of $\mathrm{Na}$ and extraction of $\mathrm{Mg}$ and $\mathrm{K}$. The preserved sedimentary structures suggest a low-temperature alteration, possibly soon after the deposition of the sediments, and the similarity of the breccias fragments with the adjacent albite schists implies that the brecciation of the strata likely commenced after the sediments were, at least partly, albitized.

\subsubsection{Origin of mudstones and albite schists}

Given the well-preserved sedimentary structures, it is unlikely that the compositions of the PFm mudstones were produced by hydrothermal alteration or metasomatism related to the meta- 
morphism. These processes would likely have resulted in obliteration of original structures and textures, veining, grain size coarsening, along-strike gradation from an unaltered rock to altered rock etc., but not in uniform mineral and chemical compositions.

No indication of volcanic activity is observed in association with the PFm, but the sediments might contain detritus derived from volcanic rocks. High contents of $\mathrm{MgO}, \mathrm{FeO}_{\text {tot }}$ and $\mathrm{TiO}_{2}$ suggest a significant mafic component in the mudstones. On the other hand, the high $\mathrm{K}_{2} \mathrm{O}$ and low $\mathrm{CaO}$ and $\mathrm{Na}_{2} \mathrm{O}$ contents suggest the opposite. Derivation solely from a mafic or felsic source is hence unlikely: no geochemical analogs are found amongst typical igneous rocks or even from the more uncommon ones (see Figs. 11, 12). Silicic tuffs have been recorded to be diagenetically $\mathrm{Na}$-metasomatized in alkaline evaporitic lake environments by reaction with Na-rich brines (Ratterman \& Surdam, 1981; Cook \& Ashley, 1992). If the albite schists were of such an origin, they would likely display trace element patterns different from those of the mudstones (Vanhanen, 2001; Bjørklykke et al., 1987). Summing up, a dominantly volcanogenic origin for the mudstones and albite schists seems unlikely.

Simple mechanical erosion of one or multiple sources is not supported either, as it would require derivation from source rocks, or a mixture of source rocks, of extreme compositions. Instead, chemical weathering in the source terrain can explain some of the compositions of the PFm mudstones. Among the most soluble elements during chemical weathering are $\mathrm{Ca}$ and $\mathrm{Na}$ showing commonly proportional losses (Kramers, 2002). Strontium is another element that is easily leached during weathering. The contents of these elements and especially that of strontium $(<50 \mathrm{ppm})$ in the PFm mudstones are lower compared to typical shales and the RGDB reference data (Figs. 11, 12B) and markedly lower compared to an average Archean upper crust with 6.2 wt. $\% \mathrm{CaO}, 3.3$ wt. $\% \mathrm{Na}_{2} \mathrm{O}$ and 240 ppm Sr (Taylor \& MacLennan, 1985). These features suggest derivation from a severely weathered source terrain for the mudstones (e.g., Absar et al., 2009), and also for the albite schists.

Residual enrichment in a chemically weathered source terrain can also explain the high contents of $\mathrm{TiO}_{2}$ and $\mathrm{FeO}_{\text {tot }}$. Titanium is relatively immobile during weathering and is enriched as rutile in weathering residues, but retention of iron requires oxidizing conditions. Hence, Fe-enriched weathering profiles started to form after the oxygenation of the atmosphere. An example of a Paleoproterozoic Feenriched paleoweathering profile, the type of which the oxides in the PFm could have been derived from, is provided by the hematitic Drakenstein-Wolhaarkop paleosol in South Africa developed on the -2.2 Ga Ongeluk and Hekpoort andesites and basalts and BIF (Wiggering \& Beukes, 1990; Beukes et al, 2002; Yang \& Holland, 2003). This lateritic paleosol contains locally ore-grade amounts of $\mathrm{Fe}$ as hematite. It is overlain by local fluvial conglomerates containing pebbles derived from the hematite ores and extensive hematite-pigmented red slates with the hematite being derived chiefly from the underlaying lateritic soils (Yamaguchi et al., 2007). Paleosols, implying significant chemical weathering, are known also in the Karelian successions (e.g., Laajoki, 2005). The -2.3 Ga Hokkalampi paleosol in North Karelia, eastern Finland, records both depletion and enrichment in Fe (Marmo, 1993).

Magnesium and potassium are also readily soluble during weathering, but they may be partly retained within the weathering profiles by clays (e.g., by chlorite, illite, montmorillonite, sepiolite and palygorskite) and other minerals (Friedman \& Sanders, 1978; Taylor \& Eggleton, 2001). During progressive weathering, also these minerals are eventually broken down and $\mathrm{Mg}$ and $\mathrm{K}$ are mobilized. If the PFm mudstones were derived from a source that was severely chemically weathered under oxidizing conditions, high $\mathrm{Fe} / \mathrm{Mg}$ and $\mathrm{Fe} / \mathrm{K}$ values in their erosional products would be expected (Reinhardt, 1992). However, this is not the case with the PFm.

It is common that $\mathrm{Mg}$ and $\mathrm{K}$ are added to sediments post-depositionally (e.g., Moine et al., 1981; Absar et al., 2009). It is also likely that $\mathrm{Mg}$ and $\mathrm{K}$ were added post-depositionally to the PFm mudstones, but not by a hydrothermal activity or 
metamorphic processes. Instead, deposition in an evaporitic environment provides plausible explanation. Referring to argillites containing magnesian clays, Moine et al. (1981) stated: "As far as major elements are concerned, high amounts of $\mathrm{Mg}$ and $\mathrm{K}$ are the main characteristic features of sediments associated with evaporites". The high $\mathrm{Mg}$ concentration results from the formation of $\mathrm{Mg}$-rich brines by evaporation and interaction of this brine with argilleous sediments where 'typical' terrigenious clays then alter to magnesian clays (such as $\mathrm{Mg}$-chlorite, sepiolite and palygorskite). In such environments, brines are $\mathrm{K}$-rich and, hence, silicates become $\mathrm{K}$ saturated. Like with the PFm mudstones, the $\mathrm{K}_{2} \mathrm{O}$ / $\mathrm{MgO}$ ratio of sediments in evaporitic basins is not fixed but varies laterally and horizontally (Moine et al., 1981; Reinhardt, 1992).

There are several lines of evidence supporting an evaporitic depositional environment for the PFm mudstones. These include their 1) high $\mathrm{MgO}$ and $\mathrm{K}_{2} \mathrm{O}$ contents, 2) high abundance of phlogopite and dravitic tourmaline, 3) shallow to subaerial depositional environment, and 4) association with stromatolitic dolomites (cf. Moine et al., 1981; Warren, 1999; Henry et al., 2008). Although no typical Mg-clays of evaporitic environments were identified, the magnesian nature of the miscellaneous phyllosilicates is notable (cf. Warren, 1999 and references therein). Also, $\mathrm{Mg}$-rich chlorite is present in some samples (Fig. 6F), and some micas and phyllosilicates contain fairly high $\mathrm{F}$ and $\mathrm{Cl}$ contents. Both features are common for metaevaporitic strata (Moine et al., 1981). Furthermore, the quartzdolomite- and albite-filled, displacive nodules in the mudstones and albite schists (Figs. 4F, G, H), respectively, closely resemble pseudomorphs after gypsum and anhydrite described from similar finegrained sedimentary rocks in the Onega Basin (e.g., Melezhik et al., 2000, 2005b, 2012; Reuschel et al., 2012). Potentially relictic grains of anhydrite can still be observed in nodules at Petäjäskoski. Where concentrated in stratiform zones (Fig. 4G), the nodules form networks that resemble the 'chicken-wire' textures. This kind of coalesced anhydrite nodules are observed, for example, in evaporitic tidal flat deposits (Warren, 1999). The radiating, quartz-dolomite-filled, sharp-faced nodules in the PFm claystones resemble evaporite minerals grown in rosette-like shapes (desert roses) (Warren, 1999).

An evaporitic depositional environment can also explain the genesis of the albite schists and the associated breccias. In the Central Lapland Greenstone Belt and Kuusamo Belt, intense albitization of sedimentary strata has been postulated to be related to halite $(\mathrm{NaCl})$ dissolution (Eilu, 1994; Vanhanen, 2001, see also Elvebakk et al., 1985). Vanhanen (2001) proposed that breccias within the albitized strata in the Kuusamo Belt are collapse breccias related to dissolution of evaporites. Of the major breccia systems associated with intense albitization and interpreted to be related to evaporate dissolution and diapirism, the Katangan breccias in the Zambian Copperbelt and the Wernecke breccias in Canada resemble, at least in part, the PFm breccias (Selley et al., 2005; Hunt et al., 2005).

Evaporite precipitation prevails at low latitudes (within $30^{\circ}$ of the equator). Though scarce, the paleomagnetic data from the Fennoscandian Shield show that at c. $2.3 \mathrm{Ga}$, the Karelian rift basins were located in the southern hemisphere at c. $20^{\circ}$, and at $1.9 \mathrm{Ga}$ ago, in the northern hemisphere at c. $20^{\circ}$ from the paleoequator (Pesonen et al., 2003; Mertanen \& Pesonen, 2005). Thus the basins seem to have passed the equator during the time interval when the Petäjäskoski Formation was deposited. Also, the Eh-pH conditions needed for lateritic weathering and the formation of hematite in red beds typically require hot tropical, humid to arid climates prevailing at near-equatorial latitudes (e.g., Friedman \& Sanders, 1978; Turner, 1980; Freyssinet et al., 2005).

There are similar sediment-hosted hematite enrichments in other Karelian supracrustal belts of the shield, of which only two are discussed here. Pekkarinen (1979) described a $\sim 1$ m thick hematite rock layer composed mainly of massive hematite from the Kiihtelysvaara area of the Finnish North Karelia (avg. $\mathrm{Fe}_{\text {tot }} 41.3 \%$ ). It is overlain by a red ferriferous slate comprising hematite, micaceous clays, chlorite, quartz, tourmaline and rutile $\left(\mathrm{Fe}_{\text {tot }}\right.$ $11.0 \%$ ). Opposed to the PFm mudstones, the fine- 
grained laminae in the slate contain less hematite than the coarser laminae. In the succeeding $-5-\mathrm{m}-$ thick quartzite, fine-grained hematite occurs in the interstitial space between quartz clasts. Pekkarinen (1979) suggested that hematite in this unit, assigned to 'Hematite rock-Quartzite Formation', was chemically precipitated from oxidized water in a shallow-water environment. A maximum depositional age for this unit is c. $2.1 \mathrm{Ga}$ (U-Pb zircon data), which is the age of mafic dikes that are assumed to represent feeders for the basaltic lavas of the Koljola Formation that occur somewhat lower in the stratigraphy (Pekkarinen \& Lukkarinen, 1991).

In the Lake Onega region in Russian Karelia, a 1-2 m thick, clastic hematite ore occurs in association with hematite-pigmented mudstones, siltstones and sandstones of the Paleoproterozoic Tulomozero Formation (Melezhik et al., 2000), which has been imprecisely dated by the $\mathrm{Pb}-\mathrm{Pb}$ method at $2090 \pm$ $70 \mathrm{Ma}$ (Ovchinnikova et al., 2007). In the mudstones, hematite has been locally enriched in the "steeper slopes of ripple marks as well as bottom sets of cross stratified beds". The Tulomozero Formation is hematite-pigmented almost through*out and most of the strata have been deposited in lacustrine to marine evaporitic environments (Melezhik et al., 2000).

\section{Conclusions}

Re-logging of drillcores intersecting an unexposed stratigraphic section led to the discovery of a previously undescribed metasedimentary unit in the Peräpohja Belt. Although basin-wide in extent and having a thickness of several hundreds of meters, the rocks lack natural outcrops. The single locality where the rocks are known to crop out is the manmade spill water channel of the Petäjäskoski hydropower station. Accordingly, the unit is assigned to the Petäjäskoski Formation.

The metasedimentary rocks of the Petäjäskoski Formation are situated stratigraphically in the middle part of the Kivalo Group, above the quartzites of the Palokivalo Formation $(>2.2 \mathrm{Ga})$ to which they were previously included. The Petäjäskoski Formation is overlain by the continental flood basalts of the -2100 Ma Jouttiaapa Formation. A mafic sill intruding the Petäjäskoski Formation was dated at $2140 \pm 11 \mathrm{Ma}$, giving a minimum age for the sedimentation. The mica-rich schists forming the bulk of the PFm have high $\mathrm{MgO}, \mathrm{K}_{2} \mathrm{O}$ and $\mathrm{FeO}_{\text {tot }}$ contents that are reflected in high abundances of phlogopite, sericite and hematite, respectively. Albite schists, containing up to 10 wt. $\% \mathrm{Na}_{2} \mathrm{O}$, likely represent albitized equivalents of the former. They are intercalated with stratabound, matrixsupported, chaotic and locally more than 30-mthick collapse breccias with clasts being composed chiefly of bounding albite schist and a matrix containing microcline, talc, chlorite, quartz and calcite.

Based on the original lithological features, the PFm can be classified as a claystone-siltstonesandstone-dolostone association. Well-preserved sedimentary structures in the siliciclastics and their association with stromatolitic dolostones imply deposition in a shallow-water to subaerial, possibly tidal environment. The Palokivalo and Petäjäskoski Formations may record a transition from reducing to oxidizing atmospheric conditions and, significantly, many independent lines of evidence suggest that evaporitic conditions prevailed, at least, part of the time during which the the Petäjäskoski Formation was deposited. Hematite in the rocks appears to be detrital in origin and is likely derived from a lateritic regolith developed under oxidizing conditions. Further studies are important for many reasons; not only because metaevaporites, preserving information about past climatic, oceanic and geographic conditions, are sparse in the early Paleoproterozoic rock record, but also because significant ore deposits, such as those belonging to the sediment-hosted stratiform copper (SSC) and iron-oxide-copper-gold (IOCG) classes, are closely linked to sedimentary basins where evaporites were deposited.

\section{Acknowledgements}

Financial support of the National Graduate School of Geology and the Pyhäsalmi Mine Oy is gratefully acknowledged, and discussions with Pasi Eilu, Hartwig Frimmel, Murray Hitzman, Timo Mäki, Tapani Mutanen, 
Juhani Ojala and Vesa Perttunen are greatly appreciated. The manuscript benefitted much from the critical reviews by Tero Niiranen and Richard Ojakangas.

\section{References}

Absar, N., Raza, M., Roy, M., Naqvi, S.M. \& Roy, A.K. 2009. Composition and weathering conditions of Palaeoproterozoic upper crust of Bundelkhand craton, Central India: Records from geochemistry of clastic sediments of $1.9 \mathrm{Ga}$ Gwalior Group. Precambrian Research 168, 313-329.

Airo, M.-L. (ed.) 2005. Aerogeophysics in Finland 1972-2004: Methods, system characteristics and applications. Geological Survey of Finland, Special Paper 39, 1-197.

Barton, M.D. \& Johnson, D.A. 1996. Evaporitic-source model for igneous-related Fe oxide-(REE-Cu-Au-U) mineralization. Geology 24, 259-262.

Bekker, A., Holland, H.D., Wang, P.L., Rumble III, D., Stein, H.J., Hannah, J.L., Coetzee, L.L. \& Beukes, N.J. 2004. Dating the rise of atmospheric oxygen. Nature 427, 117 120.

Bekker, A., Kaufman, A.J., Karhu, J.A. \& Erikson, K.A. 2005. Evidence of Paleoproterozoic cap carbonates in North America. Precambrian Research 137, 167-206.

Beukes, N.J., Dorland, H., Gutzmer, J., Nedachi, M. \& Ohmoto, H. 2002. Tropical laterites, life on land, and the history of atmospheric oxygen in the Paleoproterozoic. Geology 30, 491-494.

Berthelsen, A. \& Marker, M. 1986. 1.9-1.8 Ga old strike-slip megashears in the Baltic Shield, and their plate tectonic implications. Tectonophysics 128, 163-181.

Bhattacharya, A. 1997. On the origin of non-tidal flaser bedding in point bar deposits of the river Ajay, Bihar and West Bengal, NE India. Sedimentology 44, 973-975.

Bjørklykke, A., Hagen, R. \& Söderholm, K. 1987. Bidjovagge copper-gold deposit in Finnmark, Northern Norway. Economic Geology 82, 2059-2075.

Bowen, B.-B., Benison, K.C., Oboh-Ikuenobe, F.E., Story, S. \& Mormile, M.R. 2008. Active hematite concretion formation in modern acid saline lake sediments, Lake Brown, Western Australia. Earth and Planetary Science Letters 268, 52-63.

Condie, K.C. 1993. Chemical composition and evolution of the upper continental crust: Contrasting results from surface samples and shales. Chemical Geology 104, 137.

Cook, N.D.J. \& Ashley, P.M. 1992. Meta-evaporite sequence, exhalative chemical sediments and associated rocks in the Proterozoic Willyama Supergroup, South Australia: implications for metallogenesis. Precambrian Research 56, 211-226.

Eilu, P. 1994. Hydrothermal alteration in volcano-sedimentary rocks in the Central Lapland Greenstone Belt, Finland. Geological Survey of Finland, Bulletin 374, 1-145.
Elvebakk, G., Krill, A.G., Often, M. \& Henriksen, H. 1985. Early Proterozoic shallow-marine albite-rich sandstone in the Karasjok Greenstone Belt, Norway. Norges Geologiske Undersøkelse, Bulletin 403, 113-118.

Friedman, G.M., \& Sanders, J.E. 1978. Principles of Sedimentology. John Wiley \& Sons, New York, 792 pp.

Frietsch R., Tuisku, P., Martinsson, O. \& Perdahl J.-A. 1997. $\mathrm{Cu}-(\mathrm{Au})$ and $\mathrm{Fe}$ ore deposits associated with $\mathrm{Na}-\mathrm{Cl}$ metasomatism in early Proterozoic rocks of northern Fennoscandia: A new metallogenic province. Ore Geology Reviews 12, 1-34.

Frimmel, H.E. \& Jiang, S.-Y. 2001. Marine evaporites from an oceanic island in the Neoproterozoic Adamastor ocean. Precambrian Research 105, 57-71.

Freyssinet, Ph., Butt, C.R.M., Morris, R.C. \& Piantone, P. 2005. Ore-forming processes related to lateritic weathering. In: Hedenquist, J.W., Thompson, J.F.H., Goldfarb, R.J. \& Richards, J.P. (eds.) Economic Geology 100th Anniversary Volume, pp. 681-722.

Hanski, E. 2001. History of stratigraphical research in northern Finland. Geological Survey of Finland, Special Paper 33, 15-43.

Hanski, E.J. \& Melezhik, V.A. 2012. Litho- and chronostratigraphy of the Karelian formations. In: Melezhik, V., Prave, A., Hanski, E., Fallick, A., Lepland, A., Kump, L., Strauss, H. (eds.) Reading the Archive of Earth's Oxygenation. Volume 1: The Palaeoproterozoic of Fennoscandia as Context for the Fennoscandian Arctic Russia - Drilling Early Earth Project. Springer-Verlag, Berlin, Heidelberg, pp. 39-110.

Hanski, E., Huhma, H., \& Perttunen, V. 2005. SIMS U-Pb, $\mathrm{Sm}-\mathrm{Nd}$ isotope and geochemical study of an arkositeamphibolite suite, Peräpohja Schist Belt: evidence for ca. $1.98 \mathrm{Ga}$ A-type felsic magmatism in northern Finland. Bulletin of the Geological Society of Finland 77, 5-29.

Hanski, E., Huhma, H. \& Vuollo, J. 2010. SIMS zircon ages and $\mathrm{Nd}$ isotope systematics of the $2.2 \mathrm{Ga}$ mafic intrusions in northern and eastern Finland. Bulletin of the Geological Society of Finland 82, 31-62.

Härme, M. 1949. On the stratigraphical and structural geology of the Kemi area, northern Finland. Bulletin de la Commission Géologique de Finlande 147, 1-60.

Henry, D.J. \& Guidotti, C.V. 1985. Tourmaline as a petrogenetic indicator mineral: an example from the staurolite-grade metapelites of NW Maine. American Mineralogist 70, 1-15.

Henry, D.J., Sun, H., Slack, J.F. \& Dutrow, B.L. 2008. Tourmaline in meta-evaporites and highly magnesian rocks: perspectives from Namibian tourmalines. European Journal of Mineralogy 20, 889-904.

Henry, D.J., Novák, M., Hawthorne, F.C., Ertl, A., Dutrow, B.L., Uher, P., Pezzotta, F., 2011. Nomenclature of the tourmaline-supergroup minerals. American Mineralogist 96, 895-913. 
Hitzman, M., Kirkham, R., Broughton, D., Thorson, J. \& Selley, D. 2005. The sediment-hosted stratiform copper ore system. In: Hedenquist, J.W., Thompson, J.F.H., Goldfarb, R.J., Richards, J.P. (eds.) Economic Geology 100th Anniversary Volume, pp. 609-642.

Hölttä, P., Huhma, H., Lahtinen, R., Nironen, M., Perttunen, V., Vaasjoki, M. \& Väänänen, J. 2003. Introduction: modelling of orogeny in northern Fennoscandia. In: Eklund, O. (ed.) Lapland - 2003. Excursion Guide to Swedish and Finnish Lapland, September 1-7, 2003. Geocenter Report Nr. 20, Turku University, Åbo Akedemi, pp. 6-27.

Huhma, H., Cliff, R.A., Perttunen, V. \& Sakko, M. 1990. Sm$\mathrm{Nd}$ and $\mathrm{Pb}$ isotopic study of mafic rocks associated with early Proterozoic continental rifting: the Peräpohja schist belt in northern Finland. Contributions to Mineralogy and Petrology 104, 369-379.

Huhma, H., Mänttäri, I., Peltonen, P., Halkoaho, T., Hanski, E., Hokkanen, T., Hölttä, P., Juopperi, H., Konnunaho, J., Kontinen, A., Lahaye, Y., Luukkonen, E., Pietikäinen, K., Pulkkinen, A., Sorjonen-Ward, P. \& Vaasjoki, M. 2012. The age of the Archean schist belts in Finland. Geological Survey of Finland, Special Paper, in press.

Hunt, J., Baker, T. \& Thorkelson, D. 2005. Regional-scale Proterozoic IOCG-mineralized breccias systems: examples from the Wernecke Mountains, Yukon, Canada. Mineralium Deposita 40, 492-514.

Isomaa, J. \& Sandgren, E. 2006. Ore exploration in the years 2003 and 2005 at Kuusivaara, Muurola, Rovaniemi Municipality. Geological Survey of Finland, Archive Report M19/2633/2006/1/10, 22 pp. (in Finnish with English abstract)

Karhu, J.A. 1993. Paleoproterozoic evolution of the carbon isotope ratios of sedimentary carbonates in the Fennoscandian Shield. Geological Survey of Finland, Bulletin $371,1-87$.

Karhu, J.A. 2005. Paleoproterozoic carbon isotope excursion. In: Lehtinen, M., Nurmi, P.A. \& Rämö, O.T. (eds.), Precambrian Geology of Finland - Key to the Evolution of the Fennoscandian Shield. Elsevier B.V., Amsterdam, pp. 669-680.

Karhu, J., Kortelainen, N.M., Huhma, H., Perttunen, V. \& Sergeev, S. 2007. New time constraints for the end of the Paleoproterozoic carbon isotope excursion. 7th International Symposium on Applied Isotope Geochemistry, 10th-14th September, 2007, Stellenbosch, South Africa, pp. 76-77.

Kirkham, R.V. 2001. Sediment-hosted stratiform copper (SSC), other stratabound base metal deposits and the importance of basinal brines and/or evaporites, halotectonics and halokinesis. In: Piestrzynski, A. et al. (eds.) Mineral Deposits at the Beginning of the $21^{\text {st }}$ Century: Proceedings of the Joint Sixth Biennial SGA-SGE Meeting. Kraków, Poland, 26-29 August, 2001, A.A. Balkema Publishers,
Lisse, The Netherlands, pp. 15-18.

Kramers, J.D. 2002. Global modelling of continent formation and destruction through geological time and implications for $\mathrm{CO}_{2}$ drawdown in the Archaean Eon. Geological Society, London, Special Publications 199, 259-274.

Kotková, J., Schaltergger, U. \& Leichmann, J. 2010. Two types of ultrapotassic plutonic rocks in the Bohemian Massif coeval intrusions at different crustal levels. Lithos 115, 163-176.

Kump, L.R., Fallick, A.E., Melezhik, V.A., Strauss, H. \& Lepland, A. 2012. The Great Oxidation Event: state of the art and major unresolved problems. In: Melezhik, V., Kump, L., Fallick, A., Strauss, H., Hanski, E., Prave, A., Lepland, A. (eds.) Reading the Archive of Earth's Oxygenation. Volume 3: Global Events and the Fennoscandian Arctic Russia - Drilling Early Earth Project. SpringerVerlag, Berlin, Heidelgerg, 1517-1535.

Kyläkoski, M. 2004. Polyphase Deformation and the Relations of Vein Generations in the Kuusivaara-Vinsanmaa area in Palaeoproterozoic Peräpohja Belt, Northern Finland. Bachelors Thesis, Department of Geosciences, University of Oulu, $42 \mathrm{pp}$.

Kyläkoski, M. 2007. Nickel, Copper and Platinum-Group Element Ore Potential of the Jouttiaapa Formation, a ca. 2.1 Ga Continental Flood Basalt Sequence in the Peräpohja Belt, Northwestern Finland. Licentiate Thesis, Department of Geosciences, University of Oulu, 204 pp. (in Finnish with English abstract)

Laajoki, K. 2005. Karelian supracrustal rocks. In: Lehtinen, M, Nurmi P.A. \& Rämö, O.T. (eds.) Precambrian Geology of Finland - Key to the evolution of the Fennoscandian Shield. Elsevier B.V., Amsterdam, pp. 279-342.

Lappalainen, M. 1995. The relationship between polyphase deformation of the bedrock and low-pressure metamorphism in the Rovaniemi area. Res Terrae, Series B, No. 18, 62 pp. (in Finnish with English abstract)

Lehtonen, M., Airo, M-L., Eilu, P., Hanski, E., Kortelainen, V., Lanne, E., Manninen, T., Rastas, P., Räsänen, J. \& Virransalo, P. 1998. The stratigraphy, petrology and geochemistry of the Kittilä greenstone area, northern Finland. A report of the Lapland Volcanite Project. Geological Survey of Finland, Report of Investigation 140, 1-144. (in Finnish with English summary)

Lintinen, P. 2007. Talc investigations at Viidanmaa, Tervola, in 2005-2006. Geological Survey of Finland, Archive Report M19/2542/2007/91, 36 pp. (in Finnish with English abstract)

Marmo, J.S. 1993. The Lower Proterozoic Hokkalampi paleosol in North Karelia, Eastern Finland. In: Schidlowsky, M., Golubia, S., Kimberley, M.M. \& Trudinger, P.A. (eds.) Early Organic Evolution: Implications for Mineral and Energy Resources. Springer-Verlag, Berlin Heidelberg, pp. 41-46.

McDonough, W.F. \& Sun, S.-S. 1995. The composition of the 
Earth. Chemical Geology 120, 223-253.

Melezhik, V.A., Fallick, A.E. \& Medvedev, P.V. 2000. Palaeoproterozoic magnesite-stromatolite-dolostone-'red bed' association, Russian Karelia: palaeoenvironmental constraints on the $2.0 \mathrm{Ga}$ positive carbon isotope shift. Norsk Geologisk Tidsskrift 80, 163-186.

Melezhik., V.A., Fallick, A.E., Hanski, E.J., Kump, L.R., Lepland, A., Prave, A.R. \& Strauss, H. 2005a. Emergence of aerobic biosphere during the Archean-Proterozoic transition: Challenges of future research. GSA Today, 15, 4-11.

Melezhik, V.A., Fallick, A.E., Rychanchik, D.V. \& Kuznetsov A.B. 2005b. Palaeoproterozoic evaporites in Fennoscandia: implications for seawater sulphate, $\mathrm{d}^{13} \mathrm{C}$ excursions and the rise of atmospheric oxygen. Terra Nova 17, 141-148.

Melezhik, V.A., Huhma, H., Condon, D.J., Fallick, A.E. \& Whitehouse, M.J. 2007. Temporal constraints on the Paleoproterozoic Lomagundi-Jatuli carbon isotopic event. Geology 35, 655-658.

Melezhik, V.A., Medvedev, P.V. \& Svetov, S.A. 2012. The Onega basin. In: Melezhik, V., Prave, A., Hanski, E., Fallick, A., Lepland, A., Kump, L., Strauss, H. (eds.) Reading the Archive of Earth's Oxygenation. Volume 1: The Palaeoproterozoic of Fennoscandia as Context for the Fennoscandian Arctic Russia - Drilling Early Earth Project. Springer-Verlag, Berlin, Heidelberg, pp. 387-491.

Mertanen, S. \& Pesonen, L.J. 2005. Drift history of the shield. In: Lehtinen, M., Nurmi, P. \& Rämö, O.T. (eds.) Precambrian Geology of Finland - Key to the Evolution of the Fennoscandian Shield. Elsevier B.V., Amsterdam, pp. 645-668.

Moine, B., Sauvan, P. \& Jarousse, J. 1981. Geochemistry of evaporite-bearing series: A tentative guide for the identification of metaevaporites. Contributions to Mineralogy and Petrology 76, 401-412.

Morozov, A.F., Hakhaev, B.N., Petrov, O.V., Gorbachev, V.I., Tarkhanov, G.B., Tsvetkov, L.D., Erinchek, Yu.M., Akhmedov, A.M., Krupenik, V.A. \& Sveshnikova, K.Yu. 2010. Rock-salts in Palaeoproterozoic strata of the Onega depression of Karelia (based on data from the Onega parametric drillhole). Transactions of the Academy of Sciences 435, 230-233. (in Russian)

Mücke, A., Annor, A. \& Neumann, U. 1996. The Algomatype iron-formations of Nigerian metavolcanosedimentary schist belts. Mineralium Deposita 31, 113 122.

Naldrett, A.J. 1999. World-class Ni-Cu-PGE deposits: key factors in their genesis. Mineralium Deposita 34, 227 240.

Niiranen, T., Hanski, E. \& Eilu, P., 2003. General geology, alteration, and iron deposits in the Palaeoproterozoic Misi region, northern Finland. Bulletin of the Geological Society of Finland 75, 69-92.

Ojakangas, R.W. 1965. Petrography and sedimentation of the
Precambrian Jatulian quartzites of Finland. Bulletin de la Commission géologique de Finlande 214, 1-74.

Ojakangas, R.W., Marmo, J.S. \& Heiskanen, K.I. 2001. Basin evolution of the Paleoproterozoic Karelian Supergroup of the Fennoscandian (Baltic) Shield. Sedimentary Geology 141-142, 255-285.

Ovchinnikova, G.V., Kusnetzov, A.B., Melezhik, V.A., Gorokhov, I.M., Vasil'eva, I.M. \& Gorokhovsky, B.M. 2007. Pb-Pb age of Jatulian carbonate rocks: the Tulomozero Formation in south-eastern Karelia. Stratigraphy and Geological Correlation 4, 20-33. (in Russian)

Pekkarinen, L.J. 1979. The Karelian formations and their depositional basement in the Kiihtelysvaara-Värtsilä area, East Finland. Geological Survey of Finland, Bulletin 301, $1-141$.

Pekkarinen, L.J. \& Lukkarinen, H. 1991. Paleoproterozoic volcanism in the Kiihtelysvaara-Tohmajärvi district, eastern Finland. Geological Survey of Finland, Bulletin 357, 1-30.

Perttunen, V. 1985. On the Proterozoic stratigraphy and exogenic evolution of the Peräpohja area, Finland. Geological Survey of Finland, Bulletin 331, 131-141.

Perttunen, V. 1991. Pre-Quaternary rocks of the Kemi, Karunki, Simo and Runkaus map sheet areas. Geological Map of Finland 1 : 100 000. Explanation to the Maps of PreQuaternary Rocks, Sheets 2541 Kemi, 2542 + 2524 Karunki, 2543 Simo and 2544 Runkaus, Geological Survey of Finland, Espoo, 80 pp. (in Finnish with English summary)

Perttunen, V. \& Hanski, E. 2003. Pre-Quaternary Rocks of the Törmäsjärvi and Koivu Map Sheet Areas. Explanation to the Maps of Pre-Quaternary Rocks, Sheets 2631 and 2633. Geological Map of Finland $1: 100$ 000, Geological Survey of Finland, Espoo, 88 pp. (in Finnish with English summary)

Perttunen, V. \& Vaasjoki, M. 2001. U-Pb geochronology of the Peräpohja Schist Belt, northwestern Finland. In: Vaasjoki, M. (ed.). Radiometric Age Determinations from Finnish Lapland and Their Bearing on the Timing of Precambrian Volcano-Sedimentary Sequences. Geological Survey of Finland, Special Paper 33, 45-84.

Pesonen, L.J., Elming, S.-A., Mertanen, S., Pisarevsky, S., D’Agrella-Filho, M.S., Meert, J.G., Schmidt, P.W. \& Abrahamsen, N. 2003. Palaeomagnetic configuration of continents during the Proterozoic. Tectonophysics 375, 289-324.

Pope, M.C. \& Grotzinger, J.P. 2003. Paleoproterozoic Stark Formation, Athapuscow Basin, Northwest Canada: Record of cratonic-scale salinity crisis. Journal of Sedimentary Research 73, 280-295.

Ratterman, N.G. \& Surdam, R.D. 1981. Zeolite mineral reactions in a tuff in the Laney Member of the Green $\mathrm{Ri}$ ver Formation, Wyoming. Clays and Clay Minerals 29, 
365-377.

Rasilainen, K., Lahtinen, R. \& Bornhorst, T.J. 2007. The rock geochemical database of Finland manual. Geological Survey of Finland, Report of Investigation 164, 1-38.

Reed, M.H. 1997. Hydrothermal alteration and its relationship to ore fluid composition. In: H.L. Barnes (ed.) Geochemistry of Hydrothermal Ore Deposits, John Wiley and Sons, New York, pp. 303-366.

Reineck, H.-E. \& Wunderlich, F. 1968. Classification and origin of flaser and lenticular bedding. Sedimentology 11, 99-104.

Reinhardt, J. 1992. Cordierite-antophyllite rocks from northwest Queensland Australia: metamorphosed magnesian pelites. Journal of Metamorphic Geology 5, 451-472.

Reuschel, M., Melezhik, V.A., Whitehouse, M.J., Lepland, A., Fallick, A.E., Strauss, H., 2012. Isotopic evidence for a sizeable seawater sulfate reservoir at $2.1 \mathrm{Ga}$. Precambrian Research 192-195, 78-88.

Rossi, S. 2000. Study in order to assess the gold-copper-cobalt ore potentiality of till and erratics in the area of Tervola commune and southern Rovaniemi rural municipality. Explorations in years 1992-1995. Geological Survey of Finland, Archive Report M19/2633/2000/1/10, 70 pp. (in Finnish with English abstract)

Salonsaari, P. 1990. Deformation in the Bedrock of the Vanttauskoski Area. Masters Thesis, Department of Geosciences, University of Oulu, 62 pp. (in Finnish)

Schröder, S., Bekker, A., Beukes, N.J., Strauss, H. \& van Niekerk, H.S. 2008. Rise in seawater sulphate concentration associated with the Paleoproterozoic positive carbon isotope excursion: evidence from sulphate evaporites in the -2.2-2.1 Gyr shallow-marine Lucknow Formation, South Africa. Terra Nova 20, 108-117.

Selley, D., Broughton, D., Scott, R., Hitzman, M., Bull, S., Large, S., McGoldrick, P., Croaker, M., Pollington, N. \& Barra, F. 2005. A new look at the geology of the Zambian Copperbelt. In: Hedenquist, J.W., Thompson, J.F.H., Goldfarb, R.J. \& Richards, J.P. (eds.) Economic Geology 100th Anniversary Volume, pp. 965-1000.

Spier, C.A., de Oliveira, S.M.B., Sial, A.N. \& Rios, F.J. 2007. Geochemistry and genesis of the banded iron formations of the Cauê Formation, Quadrilátero Ferrífero, Minas Gerais, Brazil. Precambrian Research 152, 170-206.

Stacey, J.S. \& Kramers, J.D. 1975. Approximation of terrestrial lead isotope evolution by a two-stage model. Earth and Planetary Science Letters 26, 207-221.

Taylor, G. \& Eggleton, R.A. 2001. Regolith Geology and Geomorphology. John Wiley \& Sons Ltd., Chichester, 375 pp.
Taylor, R.S. \& McLennan, S.M. 1985. The Continental Crust: Its Composition and Evolution: An Examination of the Geochemical Record Preserved in Sedimentary Rocks. Blackwell Scientific Publications, Oxford, 312 pp.

Tuisku, P. 1985. The origin of scapolite in the Central Lapland schist area, northern Finland: preliminary results. Geological Survey of Finland, Bulletin 331, 159-173.

Turner, P. 1980. Continental Red Beds. Developments in Sedimentology 29. Elsevier, Amsterdam, 562 pp.

Vanhanen, E. 2001. Geology, mineralogy and geochemistry of the Fe-Co-Au-(U) deposits in the Paleoproterozoic Kuusamo Schist Belt, northeastern Finland. Geological Survey of Finland, Bulletin 399, 287 pp.

Vartiainen, R. 1996. Weathered bedrock investigations at at Lapioaapa, Rovaniemi rural municipality, in 1995-1996. Geological Survey of Finland, Archive Report M19/3611/ -96/1/83, 25 pp. (in Finnish with English abstract)

Vartiainen, R. \& Salmirinne, H. 2009. Talc investigations at Lapioaapa, Rovaniemi, in 2008-2009. Geological Survey of Finland, Archive Report M19/3611/2009/54, 19 pp. (in Finnish with English abstract)

Warren, J.K. 1999. Evaporites. Their Evolution and Economics. Blackwell, Oxford, 438 pp.

Warren, J.K. 2010. Evaporites through time: Tectonic, climatic and eustatic controls in marine and nonmarine deposits. Earth-Science Reviews 98, 217-268.

Wedepohl, K.H. (ed.). 1969. Handbook of Geochemistry. Volume 1, Springer-Verlag, Berlin, 442 pp.

Wiggering, H. \& Beukes, N.J. 1990. Petrography and geochemistry of a 2000-2200-Ma-old hematitic paleoalteration profile on Ongeluk Basalt of the Transvaal Supergroup, Griqualand West, South Africa. Precambrian Research 46, 241-258.

Xavier, R.B., Wiedenbeck, M., Trumbull, R.B., Dreher, A.M. \& Monteiro, L.V.S. 2008. Tourmaline B-isotopes fingerprint marine evaporites as the source of high-salinity ore fluids in iron oxide copper-gold deposits, Carajás Mineral Province (Brazil). Geology 36, 743-746.

Yamaguchi, K.E., Johnson, C.M., Beard, B.L., Beukes, N.J., Gutzmer, J., \& Ohmoto, H. 2007. Isotopic evidence for iron mobilization during Paleoproterozoic lateritization of the Hekpoort paleosol profile from Gaborone, Botswana. Earth and Planetary Science Letters 256, 577-587.

Yang, W. \& Holland, H.D. 2003. The Hekpoort paleosol profile in Strata 1 at Gaborone, Botswana: soil formation during the Great Oxidation Event. American Journal of Science 303, 187-220. 